\title{
Inspirasi Agustinus dan Carlo Maria Martini Bagi Keberagaman Agama di Indonesia
}

\author{
Rafael Mathando Hinganaday a,1 \\ Program Magister Teologi Universitas Sanata Dharma, Yogyakarta ${ }^{a}$ \\ do2hingansj@gmail.com ${ }^{1}$
}

\begin{tabular}{|c|c|}
\hline & ABSTRACT \\
\hline $\begin{array}{l}\text { Keywords: } \\
\text { keberagaman agama, } \\
\text { dialog antaragama, } \\
\text { lingkaran pastoral, } \\
\text { praktik iman, } \\
\text { kedamaian, } \\
\text { peran Gereja, } \\
\text { pendidikan agama }\end{array}$ & $\begin{array}{l}\text { For years people in Indonesia live together with others, who have differ- } \\
\text { ent religious backgrounds. It is, however, still difficult for some people to } \\
\text { accept religious diversity within the society. The author reflects theolog- } \\
\text { ically the question "why are there still intolerant practices, particularly } \\
\text { in religious matters, in Indonesia, although our society has been creating } \\
\text { interreligious dialogue intensively since in the past?" Using the scheme } \\
\text { of 'pastoral circle' from Joe Holland and Peter Henriot in the observation, } \\
\text { the author finds that the rejection on religious diversity in Indonesia is, at } \\
\text { first, a psychological-sociological case, which is then covered by theologi- } \\
\text { cal teachings. Therefore, beside documents, surveys published by second- } \\
\text { ary sources, and interviews with religious leaders, the author's analysis } \\
\text { is also based on the ideas of basic trust and ontological security from } \\
\text { Anthony Giddens. Augustine's De Civitate Dei and Carlo Maria Martini's } \\
\text { The Dove At Rest help the author to show that the true teaching of faith } \\
\text { to God will exactly lead people to respect others without looking at their } \\
\text { religious backgrounds. In particular, through its dialog with Martini's } \\
\text { ideas, De Civitate Dei does not merely influence this study as a treatise } \\
\text { of Christian theology, but also a source for supporting religious diversity } \\
\text { and interreligious dialog. }\end{array}$ \\
\hline
\end{tabular}

\section{PENDAHULUAN}

Pada 31 Maret 2019, Slamet Jumiarto bersama keluarganya tidak diperbolehkan tinggal di Dukuh Karet, Desa Pleret, Bantul, Yogyakarta. ${ }^{1}$ Mereka ditolak karena tidak seiman dengan warga setempat. Sudah ada kesepakatan bersama dan tertulis di dukuh tersebut sejak Oktober 2015 bahwa warga tidak akan menerima orang non-Muslim. Menghadapi aturan yang diskriminatif dan bertentangan dengan Pancasila, Slamet mengadu ke sekretaris Sultan Hamengku Buwono X, yang lalu ditindaklanjuti sampai ke Sekretaris Daerah Bantul. Mediasi yang dilakukan oleh Kepala Desa Pleret menghasilkan kesepakatan bahwa aturan diskriminatif di Dukuh Karet harus dihapus. Slamet dan keluarganya pun mengalah dan berencana pindah ke tempat lain. 
Mengingat persoalan keberagaman di dunia, termasuk Indonesia, sangatlah luas, tulisan ini dibatasi untuk secara khusus membahas tentang persoalan yang terjadi seputar upaya penerimaan atas keberagaman agama di Indonesia. Fenomena keberagaman tidak lagi dapat ditolak, khususnya di Indonesia dalam konteks zaman ini. Setiap orang diharapkan siap bertetangga dan berinteraksi dengan mereka yang berbeda agama. Untuk membantu masyarakat agar dapat menerima fenomena keberagaman, secara khusus di Indonesia kerap dilakukan upaya dialog dan kegiatan lintas iman. Akan tetapi, setelah banyak dialog, nyatanya penolakan terhadap keberagaman, khususnya dalam hal agama, masih tetap ada. Konflik antarumat beragama dan tindakan intoleran tetap terjadi pada saat ini, padahal keberagaman sudah menjadi identitas Indonesia sejak dulu, termasuk keberagaman agama.

Tulisan ini bermuara pada dorongan untuk mengupayakan penerimaan atas keberagaman agama dan meminimalisasi terjadinya praktik intoleransi agama di tengah masyarakat Indonesia. Penulis merefleksikan secara teologis pertanyaan "mengapa masih terjadi berbagai praktik intoleransi, khususnya dalam hal agama, di Indonesia, walaupun dialog-dialog sudah digencarkan sejak dulu di dalam masyarakat?" Dialog gagasan Santo Agustinus di dalam De Civitate Dei (Tentang Kota Allah) dan Carlo Maria Martini (selanjutnya penulis sebut 'Martini') di dalam The Dove At Rest membantu upaya tersebut. Untuk sampai pada refleksi teologis, penulis menggunakan 'lingkaran pastoral' (pastoral circle) dari Joe Holland dan Peter Henriot. ${ }^{2}$ Oleh karena itu, sebelum melanjutkan pembahasan, ada baiknya metode 'lingkaran pastoral' ini diperkenalkan terlebih dulu.

\section{LINGKARAN PASTORAL (PASTORAL CIRCLE)}

Skema 'lingkaran pastoral' sangat membantu di dalam studi ini. 'Lingkaran pastoral' merupakan metode analisis sosial untuk mendekati suatu persoalan sosial secara sungguh-sungguh pastoral. Pendekatan pastoral di dalam tulisan ini menganalisis suatu realitas melalui keterlibatan di dalamnya sekaligus untuk kepentingan pelayanan terkait dengan realitas tersebut. Yang ditekankan dalam lingkaran ini, seperti ditunjukkan oleh Holland dan Henriot, adalah relasi yang terus-menerus terjadi antara aksi dan refleksi seperti ditunjukkan di dalam bagan berikut. $^{3}$

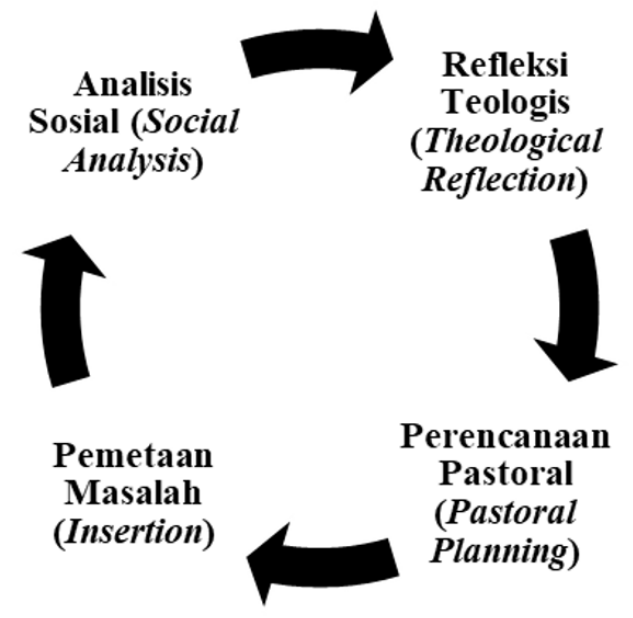

Bagan 1. Lingkaran Pastoral (Pastoral Circle)

Pembahasan diawali dengan tahap "pemetaan masalah' (insertion), yaitu pemaparan data penolakan-penolakan terhadap mereka yang berbeda agama di Indonesia. Selanjutnya, pada tahap 'analisis sosial' (social analysis), penulis berasumsi bahwa penerimaan atau penolakan terhadap mereka yang berbeda agama pada dasarnya merupakan fenomena sosiologis-psikologis, yang kemudian diselubungi dalil-dalil teologis. Pada tahap 'refleksi teologis', terkait topik penerimaan dan penolakan terhadap keberagaman agama, penulis belajar dari 
pemikiran Agustinus mengenai 'kota Allah' (civitas Dei) dalam De Civitate Dei. Gagasan Agustinus tersebut didialogkan dengan eksegese Martini atas ayat-ayat Alkitab dalam buku The Dove At Rest, yang terkait dengan tema keberagaman, tantangan, dan dukungan atas terciptanya keberagaman di dalam masyarakat. Visi hidup di dalam kedamaian yang menyentuh golongan lintas iman itulah yang penulis tampilkan di dalam beberapa tindakan konkret pada tahap 'perencanaan pastoral'.

\section{DARI KEPERCAYAAN DASAR MENUJU KEDAMAIAN}

Sumbangan penting telaah menggunakan 'lingkaran pastoral' adalah penolakan dan penerimaan atas keberagaman agama menjadi dapat dilihat secara terpilah dari pengaruh ajaran-ajaran agama. Data terkait penolakan terhadap keberagaman di Indonesia pada bagian ini memperlihatkan kasus penolakan sebagai suatu fenomena psikologis-sosiologis di tengah masyarakat Indonesia yang beragam. Penolakan atas keberagaman merupakan fenomena psikologis karena dihasilkan dari upaya pembentukan perilaku seseorang melalui norma yang hidup lingkungannya; jika di dalam suatu lingkungan penolakan sudah diangkat ke level norma, seperti dalam kasus Slamet Jumiarto, orang-orang lain di lingkungan tersebut cenderung akan mengikuti norma yang ada sehingga tidak dinilai "menyimpang”. Penolakan tersebut juga merupakan fenomena sosiologis karena tanpa perlu terburu-buru menelaah dalil agama apapun, fenomena tersebut dapat diteliti menurut data ilmiah dan konteks sosial yang berkembang pada tempat dan waktu tertentu. Oleh karena itu, penggunaan dalil keagamaan untuk menolak mereka yang berbeda keyakinan sebenarnya dapat dikritisi; dapat terjadi bahwa ada motivasi-motivasi non-religius, misalnya yang bersifat politis dan ekonomis, di balik penggunaan dalil tersebut.

Lebih lanjut akan ditunjukkan pula pada bagian ini bahwa penggunaan ajaran agama untuk melegitimasi penolakan terhadap sesama yang berbeda agama juga tidak dapat dibenarkan. Dari refleksi teologis berdasarkan dialog gagasan Agustinus dan Martini, tampak bahwa betapapun eksklusif suatu ajaran agama, rupanya arah ajaran tersebut bukanlah pada penolakan terhadap sesama. Ajaran agama justru mengajak setiap orang untuk mengarahkan diri pada kedamaian, yang mengandaikan adanya penerimaan terhadap sesama, termasuk mereka yang berbeda keyakinan. Akan tetapi, sayangnya visi ajaran agama tersebut masih belum dapat terwujud sepenuhnya di Indonesia, seperti terlihat di dalam pemaparan data berikut.

\section{Pemetaan Masalah: Narasi Penolakan dalam Berbagai Rupa}

Untuk mendalami masalah penolakan terhadap mereka yang berbeda agama, pada bagian 'pemetaan masalah' penulis menampilkan hasil penelitian dalam tiga bentuk. Pertama, hasil pengamatan penulis terhadap beberapa laporan mengenai tindakan intoleransi. Kedua, hasil survei, yang diperoleh dari beberapa institusi yang melakukan survei terkait tema seputar relasi antarumat beragama. Ketiga, hasil wawancara, yang penulis lakukan terhadap tokoh-tokoh agama. Tiga bentuk hasil penelitian dan alur tersebut penulis maksudkan agar penolakan atas keberagaman agama di Indonesia menjadi objek penelitian yang dapat dipertanggungjawabkan di dalam tulisan ini. 


\section{Laporan Dokumen: Pemerintah dan Tingkat Toleransi}

Kasus intoleransi agama tidak dapat dipandang sebagai kasus yang dalam dirinya sendiri hanya terkait dengan ajaran teologis tertentu. Beberapa institusi dan media massa justru tidak menampilkan ajaran teologis sebagai pendorong perilaku intoleran. Berdasarkan hasil studi penulis atas laporan beberapa institusi dan media massa, peran pemerintah lebih disorot sebagai faktor penting yang memengaruhi tingkat toleransi di dalam masyarakat.

Kajian SETARA Institute hingga pertengahan 2018, misalnya, memberi catatan kritis terhadap aktor-aktor negara, terutama kepolisian dan pemerintah daerah, sehubungan dengan kejadian intoleransi di Indonesia. ${ }^{4}$ Berdasarkan catatan SETARA Institute hingga 30 Juni 2018 dan dipublikasikan 20 Agustus 2018, dari 136 tindakan pelanggaran kebebasan beragama dan berkeyakinan yang tersebar di 20 provinsi. Penyelenggara negara, yang seharusnya menjadi pelopor penanaman semangat toleransi, justru menjadi pelaku utama pelanggaran kebebasan beragama dan berkeyakinan, yaitu empat belas tindakan dilakukan oleh kepolisian dan dua belas kasus dilakukan oleh pemerintah daerah. Sebagai contoh, kasus yang menimpa Slamet Jumiarto-telah penulis sampaikan di awal tulisan ini-disebabkan oleh kebijakan pemerintah setempat.

Yang juga membuat miris adalah institusi pendidikan justru masuk di dalam tiga besar pelanggar kebebasan beragama dan berkeyakinan di Indonesia dengan lima tindakan. Dengan kata lain, penanaman semangat toleransi, kebebasan beragama dan berkeyakinan melalui pendidikan tidak berjalan dengan baik. Penyelenggara negara juga ti- dak dapat memberi teladan yang baik bagi masyarakat.

Oleh karena itu, wajarlah bila menurut Social Progress Index (Indeks Kemajuan Sosial), yang dirilis oleh Social Progress Imperative pada 21 September 2018, Indonesia menempati posisi 96 dari 146 negara dalam hal 'discrimination and violence against minorities' (diskriminasi dan kekerasan melawan minoritas). ${ }^{5}$ Sementara itu, dalam hal 'freedom of religion' (kebebasan beragama), Indonesia berada pada peringkat 118. Rendahnya peringkat tersebut sebanding dengan masih rendahnya akses masyarakat ke pendidikan berkualitas (access to quality education), yang menghasilkan peringkat 97 bagi Indonesia; hal itu berarti tingkat akses masyarakat Indonesia pada pendidikan toleransi serta mendukung kebebasan beragama dan berkeyakinan juga masih rendah.

SETARA Institute juga membuat Indeks Kota Toleran pada tahun 2018, yang dilaporkan di Jakarta pada 7 Desember 2018. ${ }^{6}$ Indeks ini menilai tingkat toleransi di 94 kota di Indonesia-DKI Jakarta dihitung sebagai satu kota karena kota-kota madyanya tidak berwenang menerbitkan undang-undang. Berdasarkan empat variabel-regulasi pemerintah kota, tindakan pemerintah, regulasi sosial, demografi agama-Tanjung Balai mendapat peringkat paling rendah dalam hal toleransi. Sementara itu, predikat kota paling toleran diraih oleh Singkawang. ${ }^{7}$

Rendahnya peringkat Tanjung Balai disebabkan oleh rendahnya nilai pada aspek terjadinya kasus intoleransi dan tindakan nyata pemerintah dalam menangani kasus intoleransi tersebut, walaupun ditunjang oleh peraturan daerah. Kasus intoleransi yang mencolok di daerah ini adalah perusakan beberapa kelenteng dan wihara pada 29 Juli 
2016 oleh pemuda-pemuda Tanjung Balai setelah Meiliana—salah seorang wargamengeluhkan kerasnya suara azan di mesjid dekat rumahnya; Meiliana sendiri dihukum penjara selama 18 bulan dengan tuduhan penistaan agama. ${ }^{8}$

Rendahnya penilaian tersebut didukung oleh rendahnya tingkat heterogenitas dan inklusi sosial masyarakat terkait agama, yang berarti juga minimnya kesempatan berinteraksi dengan orang-orang berbeda agama setiap hari. Berbeda dari Singkawang, yang sebenarnya juga rendah dalam hal heterogenitas agama di dalam masyarakat, tapi pemerintah memberi dukungan nyata agar dinamika masyarakat mendukung terciptanya toleransi. Dalam hal ini, tinggi-rendahnya heterogenitas atau homogenitas terkait agama di dalam masyarakat sangat memengaruhi tingkat toleransi atau intoleransi. Oleh karena adanya potensi seperti itulah peran pemerintah menjadi amat penting untuk mengelola inklusi dan interaksi antarelemen di dalam masyarakat, terutama yang komposisi mayoritas-minoritasnya timpang.

Ada dua hal yang dapat disimpulkan dari data dokumen di atas. Pertama, minimnya tingkat keberagaman agama di dalam masyarakat ternyata bukanlah penghalang bagi terciptanya keinginan saling menghargai satu sama lain. Kota Singkawang telah membuktikan hal tersebut. Kedua, pemerintah berperan penting dalam menanamkan nilai toleransi, baik melalui kebijakan, tanggapan dan tindakan nyata ketika peristiwa intoleransi terjadi. Minimnya dukungan pemerintah bagi toleransi-bukan terutama ajaran teologis yang eksklusif dari suatu agamajustru ikut mengembangkan penolakan terhadap mereka yang berbeda agama. Dengan kata lain, pendidikan nilai toleransi tidak dapat diandaikan terjadi begitu saja karena berpotensi hilang dari permukaan dan perlahan membentuk warga menjadi intoleran, seperti yang disajikan melalui hasil survei pada bagian berikut.

\section{Hasil Survei: Dari Pendidikan ke Ranah Umum}

Pada bagian ini, penulis menampilkan terlebih dulu hasil survei yang dilakukan oleh Pusat Pengkajian Islam dan Masyarakat (PPIM) Universitas Islam Negeri (UIN) Syarif Hidayatullah Jakarta. Pada 1 September-7 Oktober 2017 PPIM mengadakan survei terhadap 264 guru dan 58 dosen Pendidikan Agama Islam, serta 1522 siswa dan 337 mahasiswa beragama Islam yang tersebar di seluruh Indonesia. ${ }^{9}$ Fokus survei ini terletak pada upaya melihat tingkat radikalisme dan intoleransi di dalam lingkungan Islam yang bersifat akademik.

Hasil survei menunjukkan bahwa pendidikan agama di sekolah ternyata memberi pengaruh dalam diri para siswa atau mahasiswa untuk tidak bergaul dengan pemeluk agama lain. Total ada 48,95\% responden yang mengatakan demikian. Rinciannya adalah 25,77\% responden merasakan pengaruh "cukup besar" dari pendidikan agama, sedangkan 23,18\% responden mengatakan "sangat besar". ${ }^{10}$

Pengaruh untuk tidak bergaul dengan para pemeluk agama lain ternyata tidak selalu ditanamkan melalui ajaran untuk menjauhi mereka. Pengaruh itu juga dapat dibiasakan melalui fokus materi yang diajarkan kepada peserta didik. Dari survei yang sama, misalnya, dapat dilihat bahwa sebanyak 63,47\% responden siswa dan mahasiswa menilai paling banyak menerima materi mengenai keimanan, ketakwaan, dan ibadah dalam Pendidikan Agama Islam. Hanya 12,96\% responden yang merasa mendapat penekanan tentang "menghargai 
orang lain yang berbeda" ketika belajar soal akhlak. ${ }^{11}$ Dengan kata lain, penanaman nilai penghargaan terhadap orang lain yang berbeda masih kurang mendapat porsi dalam Pendidikan Agama Islam di berbagai tempat.

Sementara itu, kecenderungan intoleransi tidak hanya berkaitan dengan pemeluk agama non-Islam, tapi juga terjadi di dalam tubuh agama Islam sendiri terhadap mereka yang menganggap diri Islam. Kecenderungan itu terutama tampak dari penolakan terhadap mereka yang mengikuti aliran Islam yang berbeda, misalnya Syiah dan Ahmadiyah. Tercatat ada 54,70\% guru yang tidak mau Pendidikan Agama Islam mengakomodasi sikap toleran terhadap penganut Syiah. Sejalan dengan angka tersebut, 53,60\% guru menolak jika Pendidikan Agama Islam mengajarkan sikap toleran terhadap penganut Ahmadiyah. Sebagian dosen yang menjadi responden terkait dengan topik yang sama justru menunjukkan sikap yang lebih toleran karena hanya 28,10\% responden yang menyatakan penolakan. ${ }^{12}$ Guru atau dosen yang intoleran lalu dapat menjadikan pendidikan agama untuk membentuk seseorang menjadi radikal dan intoleran pula. Menurut penulis, data tersebut juga dapat menjadi cermin bagi pendidikan agama non-Islam.

Terkait adanya sikap intoleran di antara responden siswa dan mahasiswa, akses ke Internet mendapat perhatian di dalam survei PPIM. Berdasarkan hasil survei, opini moderat cenderung diberikan oleh responden yang tidak memiliki akses Internet, padahal jumlah mereka hanya 15,06\%. Mereka yang dapat mengakses Internet memperoleh pengetahuan keagamaan dari sana pula, termasuk dengan mengakses situs-situs radikal atau akun-akun radikal di media sosial.
Bukan hanya di lingkungan pendidikan, kecenderungan intoleransi juga muncul dalam lingkungan masyarakat umum, bahkan lingkungan terkecil, yaitu sekitar tempat tinggal. Hal itu dapat dilihat, misalnya, dari data yang dihimpun oleh Lembaga Survei Indonesia (LSI). ${ }^{13}$ Survei yang dilakukan pada 1-7 Agustus 2018 ini membedakan responden berdasarkan kategori Muslim dan Non-Muslim. Dari 1.520 responden berusia 17 tahun ke atas yang disurvei, 87,1\% responden beragama Islam.

Hasil survei lalu menunjukkan temuan, yaitu dari 87,1\% responden Muslim tersebut, 38\% merasa keberatan bila umat nonMuslim mengadakan kegiatan peribadatan di lingkungan sekitar domisili mereka. Sementara itu, 54\% responden tidak merasa keberatan. Menariknya, jika dibandingkan dengan hasil survei serupa yang juga dilakukan oleh Lembaga Survei Indonesia setahun sebelumnya, tampak peningkatan 2\% responden yang merasa keberatan, sedangkan prosentase mereka yang tidak keberatan turun sebanyak 3\% pada tahun ini.

Prosentase lebih besar diperlihatkan dalam pembicaraan mengenai penolakan pendirian tempat ibadah umat yang tidak seiman. Hasil survei yang sama menunjukkan bahwa 52\% responden Muslim merasa keberatan jika umat non-Muslim mendirikan tempat ibadah di lingkungan mereka, sementara 39\% responden tidak keberatan. Seperti dalam topik kegiatan peribadatan, tren penolakan responden mengalami peningkatan dari hasil survei tahun lalu, yaitu sebesar 4\%; penurunan dengan prosentase yang sama dialami pada responden yang tidak keberatan. ${ }^{14}$

Walaupun dalam jumlah yang lebih kecil, penolakan terhadap kehadiran mereka yang beragama lain juga terjadi di antara respon- 
den non-Muslim. Untuk pertanyaan-pertanyaan yang sama ditemukan hasil berikut: masih ada 5\% dari 196 responden non-Muslim yang keberatan akan adanya kegiatan peribadatan Muslim di lingkungan mereka, sementara $12 \%$ responden keberatan jika umat Muslim mendirikan tempat ibadat di lingkungan mereka. Yang membawa nuansa positif di sini adalah jumlah responden non-Muslim yang menerima keberadaan mereka yang berbeda agama, baik dalam bentuk kegiatan peribadatan maupun rumah ibadat, ternyata jauh lebih besar, yaitu masing-masing 84\% dan 70\%. ${ }^{15}$

Hal lain yang ditemukan ketika melanjutkan pemaparan atas hasil-hasil survei terkait relasi antariman adalah adanya motif non-teologis yang ikut melatarbelakangi penolakan terhadap mereka yang berbeda agama. Motif ekonomi dan politik tampak dominan. Artinya, penolakan dilakukan ketika kelompok atau orang berbeda agama dianggap tidak mendukung atau membawa manfaat dalam upaya masyarakat sekitarnya melakukan tindakan ekonomi (motif ekonomi); demikian pula, penolakan yang sama juga dilakukan saat kaum berbeda agama dinilai dapat menghambat pihak penolak untuk meraih, mempertahankan, dan melaksanakan kekuasaan (motif politik). Menurut penulis, hal itu dapat dipahami karena bidang ekonomi dan politik memang berkaitan dengan hajat hidup orang banyak.

Hasil survei PPIM, misalnya, memperlihatkan bahwa di satu sisi ada 83,85\% responden guru dan dosen, serta 79,07\% responden siswa dan mahasiswa yang setuju bahwa orang Kristen bukan musuh orang Islam. Hal yang senada dengan data tersebut ditunjukkan oleh hasil survei yang sama, yaitu $64,60 \%$ responden guru dan dosen, serta 70,36\% responden siswa dan maha- siswa tidak keberatan bila mereka yang berbeda agama memberi bantuan kepada lembaga-lembaga Islam. Akan tetapi, di sisi lain, survei yang sama menunjukkan bahwa ada 54,35\% responden guru dan dosen, serta $48,04 \%$ responden siswa dan mahasiswa yang berpendapat orang non-Muslim lebih diuntungkan secara ekonomi daripada orang Muslim. Sebanyak 40,06\% responden guru dan dosen, serta 36,79\% responden siswa dan mahasiswa bahkan berpendapat bahwa orang non-Muslim bertanggung jawab atas ketimpangan sosial ekonomi di Indonesia. ${ }^{16}$

Sementara itu, terkait bidang politik, survei Centre for Strategic and International Studies (CSIS), yang dilakukan pada 2330 Agustus 2017 terhadap 1.000 responden, menunjukkan bahwa hanya 39,1\% responden dapat menerima pemimpin yang berbeda agama. ${ }^{17}$ Menurut data yang dihimpun Lembaga Survei Indonesia, umat Muslim yang keberatan bila dipimpin oleh orang non-Muslim mencapai lebih dari 50\%, yaitu 52\% jika non-Muslim menjadi bupati/ walikota dan gubernur, 55\% jika non-Muslim menjadi wakil presiden, dan 59\% jika non-Muslim menjadi presiden. ${ }^{18}$

Seperti telah ditunjukkan sebelumnya, hasil survei menangkap secara kuat bahwa ada motif menguasai hajat hidup masyarakat, terutama di dalam bidang politik dan ekonomi. Oleh karena itu, dapat dipahami bahwa sentimen agama, suku, ras, dan golongan berpeluang untuk dijadikan sebagai legitimasi kekerasan yang dilakukan oleh mereka yang terlibat dalam konflik. Alasannya adalah karena posisi "siapa yang berkuasa dan tidak berkuasa" dapat dimainkan di situ; sentimen "mayoritas-minoritas", misalnya, dapat dimanfaatkan untuk menunjukkan posisi "siapa yang berkuasa dan tidak berkuasa" di hadapan orang yang ditekan. 
Dengan ditunjukkan oleh data dari PPIM, CSIS, dan LSI di atas, penulis melihat bahwa motif politik dan ekonomi menjadikan suatu penolakan berbeda dari penolakan yang dilakukan hanya karena seseorang berbeda agama atau karena mendirikan tempat ibadah untuk umat yang berbeda agama. Letak perbedaannya, seperti telah disinggung sebelumnya, persis terletak pada seberapa besar manfaat ekonomis dan politis yang dapat dihadirkan oleh mereka yang berbeda agama bagi orang-orang yang ingin mewujudkan motif politik dan ekonomi mereka. Penolakan terhadap pemimpin berbeda agama, misalnya, tidak akan terjadi ketika pemimpin tersebut dapat mengakomodasi motif politik mereka yang berpotensi melakukan penolakan tersebut. Demikian pula, masyarakat beragama mayoritas dapat saja mengizinkan warga minoritas mendirikan tempat ibadat, tapi akan menolak jika kaum minoritas itu sudah dinilai mengusik ranah kekuasaan politis yang dipegang oleh kaum yang menganggap diri mayoritas.

Dari seluruh hasil survei di atas dapat ditarik tiga pokok kesimpulan. Pertama, di dalam kurikulum akademis, intoleransi memang tidak ditanamkan melalui ajaran agama yang mengandung kebencian. Akan tetapi, kurikulum ajaran agama yang eksklusif, serta tidak masuknya pendidikan toleransi dan relasi lintas iman di dalam kurikulum pendidikan agama ternyata ikut menyumbang munculnya perilaku intoleran. Hal ini amat berkaitan dengan peran pemerintah sebagai pemangku kebijakan, seperti diperlihatkan pada hasil penelitian dokumen di bagian sebelumnya.

Kedua, hasil survei di atas memperkuat bukti bahwa keberagaman dalam dirinya sendiri bukanlah inti persoalan di dalam relasi lintas iman di Indonesia. Berdasarkan survei, cukup besarnya angka penolakan responden terhadap mereka yang tidak seiman justru berbanding sejajar dengan tidak adanya muatan pendidikan toleransi di dalam kurikulum pendidikan agama. Ketiga, selain perbedaan pandangan teologis di dalam lingkup agama tertentu atau lintas agama, aspek ekonomi dan politik juga muncul sebagai pendorong penolakan terhadap mereka yang tidak seiman. Hal itu berarti memahami perilaku intoleransi agama tidak relevan tanpa juga mempertimbangkan kemungkinan adanya motivasi lain dari penolakan terhadap umat beragama lain. Hasil wawancara dengan tokoh-tokoh agama berikut ini, yang bersentuhan langsung dengan persoalan yang terjadi di dalam relasi lintas iman, semakin memperkuat temuantemuan yang sudah ada.

\section{Wawancara Tokoh Agama: Narasi Ketertindasan - Praktik Kekerasan}

Temuan-temuan pada bagian sebelumnya terkonfirmasi melalui wawancara penulis dengan Jay Akhmad, Koordinator Sekretariat Nasional Jaringan Gusdurian, dan RD. F. X. Endra Wijayanto, Koordinator Komisi Karya Keadilan, Perdamaian, dan Keutuhan Ciptaan Keuskupan Agung Semarang (KKPKC-KAS). Menurut Jay Akhmad, dalam wawancara tanggal 25 Maret 2019 di Griya Gusdurian, Yogyakarta, penanaman nilainilai keagamaan, termasuk yang mendorong seseorang menjadi toleran atau tidak, tidak hanya terjadi secara formal di sekolah, melainkan juga melalui media sosial. "Karena ini kita asumsikan menjadi pintu masuk pikiran banyak orang berubah di dunia nyatanya," demikian jelas Akhmad. ${ }^{19}$

Akhmad menyampaikan sekurang-kurangnya dua narasi yang disebarkan kelompok garis keras mengenai agama mayoritas di Indonesia. ${ }^{20}$ Kedua narasi itu sejalan de- 
ngan hasil survei PPIM yang memperlihatkan sejumlah responden yang meyakini ketertindasan umat agamanya dan orang non-Muslim sebagai pihak yang lebih diuntungkan dalam hal sosial ekonomi di Indonesia. Narasi yang pertama adalah umat agama mayoritas di Indonesia berada dalam situasi tertindas dan terpinggirkan. Narasi ini berlanjut ke narasi kedua, yaitu umat agama tersebut harus bersatu, apapun pahamnya, demi mengembalikan kejayaan agama tersebut. Narasi besar, seperti juga sudah dimunculkan di dalam survei, telah berkembang luas, terutama melalui media sosial, selain juga melalui pertemuan-pertemuan keagamaan.

Bentuk lain tindak intoleransi yang seolah-olah menyinggung aspek teologis dan religius, tapi bermuatan politis juga disampaikan oleh RD. F. X. Endra Wijayanto. Romo Endra-sapaan beliau-penulis wawancarai pada 21 Februari 2019 di Pastoran Paroki St. Yusuf Pekerja, Gondangwinangun, Klaten. ${ }^{21}$ Kasus penolakan terhadap peribadatan non-Muslim pertama kali beliau tangani pada tahun 2016 di Candi, yang masuk dalam teritori Paroki Keluarga Kudus, Banteng, Yogyakarta. Yang menjadi korban adalah seorang umat bernama Pak Julius, yang juga mengalami kekerasan fisik. "Mereka itu melakukan doa rosario di satu rumah, rumahnya Pak Julius, yang kemudian dilempari batu," demikian ungkap Romo Endra.

Walaupun fenomenanya adalah intoleransi agama, beliau mengakui bahwa intimidasi tersebut disinyalir juga berbau politis. Menurut beliau, yang diincar di sana sebenarnya adalah kematian Pak Julius sendiri terkait dukungannya terhadap calon presiden tertentu. Walaupun demikian, dampak teror tersebut akhirnya tidak hanya dialami
Pak Julius, tetapi juga oleh umat lingkungan Candi.

Terlepas dari motif non-teologis yang mendasarinya, penolakan terhadap umat, kegiatan, dan tempat ibadat agama lain, seperti telah ditunjukkan oleh survei, terkonfirmasi di dalam tindak kekerasan konkret. Karena sudah menjurus pada kriminalitas, betapapun diselubungi oleh suatu pemikiran teologis, penolakan tersebut juga memperlihatkan aspek sosiologisnya. Penolakan itu menjadi masalah dalam hidup bersama di dalam masyarakat, yang terlebih dulu dapat ditelaah dan ditangani secara sosiologis sebelum beranjak ke pemikiran teologis.

Seperti dikisahkan pula oleh Romo Endra, dan sempat diberitakan di media massa, kekerasan-yang terjadi ketika korban sedang melakukan ibadat-juga muncul di Bedog, Yogyakarta. Korbannya antara lain adalah Pater Karl Edmund Prier, SJ, yang sedang memimpin perayaan Ekaristi ketika serangan terhadap umat Kapel Bedog berlangsung. Peristiwa tersebut lebih ditanggapi secara keras oleh Komisi KKPKC karena serangan itu terjadi di dalam suatu perayaan Ekaristi. Tindakan itu sama dengan penistaan karena, bagi Romo Endra, "menghancurkan pokok jantung iman orang Katolik."22

Tindak intoleransi menjurus kriminal juga terjadi dalam bentuk pemotongan nisan salib di Pringgolayan, Yogyakarta. Menurut cerita yang beredar, makam tempat jenazah Bapak Slamet dimakamkan itu adalah makam Muslim; almarhum mendapat izin untuk dimakamkan di sana sebagai warga yang sudah dikenal baik, asalkan tidak memasang salib di sana. Romo Endra beserta tim juga ikut mendampingi keluarga $\mathrm{Bu}$ Slamet yang menjadi korban. Awalnya, beliau cenderung tidak ingin terlalu mempersoalkan peristiwa tersebut bila yang terjadi 
hanya pemotongan salib. "Oke. Kalau hanya sekadar pemotongan salib, kita tidak usah terlalu banyak bergeraklah," kata beliau kepada para aktivis KKPKC-KAS. Akan tetapi, beliau kemudian masuk ke ranah kasus tersebut setelah mendengar adanya pelarangan misa tujuh hari di sana; sebelumnya, ibadat rosario dan APP lingkungan juga pernah dilarang. Bagi beliau, rangkaian peristiwa tersebut menjadi jelas sebagai kasus intoleransi.

Peristiwa serupa juga ternyata terjadi di Mojokerto, Jawa Timur, tidak lama setelah berlangsungnya peristiwa Pringgolayan, seperti diungkapkan Akhmad. ${ }^{23}$ Yang menarik adalah pendampingan korban justru dilakukan oleh anggota Jaringan Gusdurian, kelompok beridentitas keagamaan sama dengan warga yang menolak nisan salib. Kemungkinan pendampingan lintas iman seperti itu tercipta sejalan dengan penjelasan Romo Endra, yang mengatakan bahwa Keuskupan Surabaya memang belum memiliki Komisi KKPKC. ${ }^{24}$ "'Sampeyan ki tetep bener. Ora usah wedi. Tetep ana sing ngancani ki, santae ae, rapapa. ${ }^{25}$ Gusdurian ada di belakangmu,' istilahnya gitu," demikian Akhmad menegaskan peran Jaringan Gusdurian Mojokerto dalam kasus itu.

Dengan kata lain, penolakan terhadap umat berbeda agama itu sungguh nyata dan menjadi perhatian semua orang, bukan hanya umat yang dianggap minoritas dalam masyarakat. Yang disayangkan adalah, terutama oleh Romo Endra, pihak pembesar Gereja, mulai dari level keuskupan hingga paroki, hanya diam dan menyelubungi sikap diam itu dengan ajaran Yesus mengenai pengampunan. Sikap diam itu terjadi baik terkait kasus di Bedog maupun Pringgolayan dan Mojokerto.
Dari pemaparan wawancara di atas, ada tiga hal yang dapat ditarik sebagai kesimpulan. Pertama, pendidikan atau penanaman nilai, khususnya terkait dengan agama, dipahami secara lebih luas. Penanaman nilai toleransi tidak dapat hanya dilakukan dengan meninjau pendidikan agama di sekolah atau perkumpulan keagamaan, tapi juga dengan menggarap media sosial.

Kedua, tersebar luasnya narasi ketertindasan suatu agama berjalan sejajar dengan upaya umat agama tersebut untuk menggunakan kekerasan dan ancaman terhadap mereka yang dianggap menindas, yaitu umat beragama lain. Artinya, narasi mengenai "tertindasnya suatu agama" dimunculkan sebagai kerangka yang membingkai dan tidak terpisahkan dari seluruh aksi kekerasan dan ancaman terhadap target yang dibenci. Narasi ketertindasan agama memberi alasan religius dan semangat kepahlawanan dalam suatu aksi kekerasan. Aksi kekerasan dan ancaman itu sendiri sejatinya tidak memerlukan narasi ketertindasan agama; akan tetapi, tanpa narasi itu, kekerasan dan ancaman hanya menjadi sebentuk tindak kriminal tanpa dasar dan tidak berbeda dari pencurian, perampokan, atau aksi kejahatan biasa. Oleh karena itu, narasi keagamaan yang tersebar dan ditanamkan pada masyarakat umum harus ditanggapi secara serius.

Ketiga, peran dan suara lembaga keagamaan sangat penting untuk melawan intoleransi. Bahkan, kerja sama yang bersifat lintas iman antar lembaga keagamaan untuk melawan intoleransi dapat dilakukan untuk menutup lubang yang tercipta akibat tidak adanya suara dari lembaga keagamaan yang umatnya menjadi korban.

Data yang diperoleh dari berbagai sumber di atas memperlihatkan gambaran 
konkret kemampuan masyarakat Indonesia dalam menerima fenomena keberagaman, khususnya dalam hal agama. Sementara ada sebagian orang yang berperilaku toleran dan dapat menerima keberagaman, ada pula yang berperilaku sebaliknya. Baik prosentasenya besar maupun kecil, kedua kubu tersebut tetap harus diperhatikan sebagai faktor penentu keberlangsungan hidup bersama di dalam masyarakat Indonesia yang majemuk ini. Terlepas dari unsur teologis yang disertakan untuk menyelubungi penolakan atas keberagaman agama, fenomena tersebut dapat dijelaskan dengan menggunakan analisis dan pemikiran sosial seperti yang akan dilakukan pada tahap selanjutnya.

Penulis perlu memberikan catatan dalam hal ini. Dengan data hasil survei di atas, penulis menyadari kemungkinan terjadinya salah paham dan anggapan bahwa ada pihak-pihak tertentu yang merasa dipojokkan. Oleh karena itu, untuk mencegah salah paham dan perasaan terpojokkan, penulis terangkan bahwa lingkungan Islam menjadi fokus survei-survei di atas dalam kerangka Islam sebagai agama yang dipeluk oleh mayoritas warga di Indonesia. Artinya, hasil dan kesimpulan yang berbeda mungkin saja terjadi bila agama lainlah yang dipeluk oleh mayoritas penduduk Indonesia atau diberlakukan dalam konteks masyarakat non-Indonesia. Demikian pula, dengan mengubah subjek penelitian dalam survei, ada kemungkinan pula bahwa angka serupa masih akan muncul. Penggunaan hasil survei di atas merupakan upaya penulis untuk seobjektif mungkin mengontekstualkan analisis yang akan diberikan pada bagian berikutnya menjadi hanya untuk kasus Indonesia.

\section{Analisis Sosial: Kepercayaan Dasar - Keamanan Ontologis}

Dari hasil pemetaan masalah di atas, pada bagian ini penulis kembali mengidentifikasi dan memperjelas persoalan yang ada di dalam data pengalaman. Persoalan yang ada di dalam setiap pengalaman itu adalah pandangan dan perlakuan diskriminatif atas mereka yang dianggap berbeda agama. Pandangan dan perlakuan diskriminatif yang sama juga terjadi pada pembela mereka.

Seperti sudah disinggung sebelumnya, keberagaman itu sendiri sebenarnya bukanlah akar persoalan dari segala konflik yang terjadi atas nama 'perbedaan', 'keberagaman', 'kemajemukan', 'pluralitas', atau semacamnya. Anthony Giddens menunjukkan bahwa aktivitas semua manusia secara dominan dipengaruhi oleh unsur yang disebut 'keamanan ontologis' (ontological security). ${ }^{26}$ Keamanan ontologis ini merupakan karakter yang muncul dalam level praktis hidup manusia, yang juga dipengaruhi oleh kesadaran praktis (practical consciousness) manusia.

Dengan istilah 'keamanan ontologis', Giddens ingin mengatakan bahwa pada dasarnya manusia ingin hidup dalam rasa aman dan terjamin. Kebiasaan, rutinitas, dan perhatian yang diberikan oleh orang lain secara terus-menerus menjadi ungkapan-ungkapan yang menimbulkan rasa aman dan terjamin. Secara khusus, ketiganya-kebiasaan, rutinitas, dan perhatian terus-menerusmembentuk suatu kepercayaan dasar (basic trust), yaitu kepercayaan seseorang akan adanya perlindungan dan rasa aman bagi dirinya sendiri, walaupun sosok yang melindungi itu tidak terlihat. ${ }^{27}$ 
Hal-hal eksistensial yang melekat pada keber-ada-an manusia di dunia, seperti waktu, jarak, keberlanjutan, dan identitas pada umumnya juga manusia terima begitu saja (take for granted) tanpa dipertanyakan lagi. Karena sudah menjadi rutin atau melekat secara eksistensial pada dirinya, seseorang juga tidak selalu dapat menjelaskan alasannya melakukan ini dan itu, atau merasa ini dan itu. Hal-hal tersebut biasanya baru ditanyakan ketika seseorang sedang berfilosofi atau saat sedang mengalami krisis psikologis $^{28}$. Di sinilah kesadaran praktis berperan penting dalam pembentukan kepercayaan dasar, dan kemudian pada pembentukan rasa aman ontologis, karena seseorang diajak untuk sadar akan apa yang ia lakukan dan alasan ia melakukannya tanpa ia perlu menjelaskan alasannya kepada pihak lain.

Bagi Giddens, kepercayaan dasar tidak menutup kenyataan bahwa risiko (risk) sudah menjadi unsur yang melekat dalam keberlangsungan hidup (the sustaining of life) manusia, baik yang bersifat fisik maupun psikologis. ${ }^{29}$ Ketika manusia menjadi perlu berbagi dan berjumpa dengan orang lain, muncul pula kemungkinan untuk terjadinya kekacauan (chaos). Orang lain secara psikologis dapat menimbulkan kecemasan (anxieties) karena kebiasaan-kebiasaan baru yang mereka bawa dan cara pandang baru yang mereka tawarkan untuk melihat realitas. Kecemasan seseorang berasal terutama dari kegagalannya, dalam kadar tertentu, untuk membuka ruang bagi terbentuknya kepercayaan dasar. ${ }^{30}$ Risiko dapat mengguncang berbagai hal yang sudah membentuk keamanan ontologis seseorang.

Sementara itu, orang yang dapat membentuk kepercayaan dasar tidak berarti ia dapat menghilangkan risiko dalam hidup. Nyatanya ia memang tidak menghilangkan risiko tersebut karena, bagi Giddens, kepercayaan itu juga dapat berarti "menghadapi kemungkinan akan kehilangan" (to face the possibility of loss), yaitu kehilangan sosok yang dianggap mampu menjadi pelindung. ${ }^{31}$ Akan tetapi, mereka yang dapat membentuk kepercayaan dasar akan mampu mengolah risiko dengan kreatif. Ia akan mengerahkan segala daya upaya (effort) untuk "memeluk suatu pengalaman baru" (to embrace novel experiences) atau, dalam ungkapan lain, melakukan "lompatan ke dalam ketidaktahuan" (leap into the unknown). ${ }^{32}$

Gagasan Giddens tersebut kemudian dapat membantu dalam memahami keberagaman yang dialami oleh masyarakat Indonesia beserta seluruh dinamika yang tercipta sebagai akibat dari keberagaman tersebut. Keberagaman suku, ras, agama, dan golongan merupakan bagian dari dinamika hidup bermasyarakat di Indonesia sejak bangsa ini merdeka. Selain itu, yang juga perlu dicatat dalam kerangka pemikiran Giddens, setiap individu yang menyusun masyarakat Indonesia pun beraneka ragam. Setiap individu ini juga dibentuk dengan latar belakang berbeda-beda, termasuk dalam hal pembentukan kepercayaan dasar. Seandainya pun seseorang tidak lahir dan dibesarkan dalam lingkungan yang langsung mengalami keberagaman ini, fakta bahwa ia adalah warga negara Indonesia menjadikan dirinya atau keluarganya tetap perlu mengantisipasi perjumpaannya dengan fenomena keberagaman.

Bertolak dari pemikiran Giddens, dapat ditarik kesimpulan bahwa perilaku diskriminatif dan penolakan terhadap keberagaman dilakukan tergantung pada level kemampuan seseorang dalam mengolah ketidakpastian dan risiko yang mungkin disebabkan oleh ketidakpastian itu. Di te- 
ngah kebutuhan akan kepastian-yang, antara lain, dibentuk oleh rutinitas—sebagai bahan baku terbangunnya kepercayaan dasar, keberagaman di dalam masyarakat dapat dipandang lebih mengandung ketidakpastian dan berpotensi memunculkan risiko lebih besar. Oleh karena itu, semakin ia tidak mampu mengolah ketidakpastian dan risiko yang mengikutinya, seseorang akan memilah dan menjauhkan faktor penyebab ketidakpastian itu-yaitu keberagaman dan mereka yang berbeda-dari dirinya. Wujudnya muncul dalam bentuk perilaku diskriminatif. Akan tetapi, bagi orang yang mampu mengolah ketidakpastian dan risiko, sehingga kepercayaan dasarnya semakin besar, ia akan semakin merasa aman hidup dengan mereka yang berbeda.

Pada satu sisi, bila dibaca dengan bantuan gagasan Giddens, mereka yang sudah merasa aman secara ontologis bisa jadi berpotensi tidak melakukan tindakan diskriminatif. Kepercayaan dasar mereka sudah terbentuk dengan relatif baik. Mereka juga tidak akan memandang sesama terutama sebagai ancaman karena di dalam kesadaran mereka sudah terbentuk rasa aman dan terlindungi. Sebaliknya, orang yang memiliki tingkat keamanan ontologis rendah berpotensi paling besar untuk menjadi pelaku tindakan diskriminatif. Mereka tidak merasa aman ketika berada bersama siapapun karena kepercayaan dasar mereka belum terbentuk dengan baik. Mereka akan selalu merasa tanpa perlindungan dan kehadiran orang dianggap sebagai suatu ancaman.

Di sisi lain, pertanyaan yang kemudian dapat muncul adalah "apakah tidak mungkin seseorang dapat merasa aman dengan dirinya yang membenci sesama yang berbeda?" Dibaca dengan kacamata pemikiran Giddens, potensi tersebut pun ada. Seper- ti yang telah ditunjukkan Giddens, rasa aman ontologis seseorang datang dari terus berlangsungnya narasi partikular tentang dirinya (continuity of biography) yang membentuk identitas seseorang, serta mengandaikan adanya penerimaan atas realitas, baik realitas mengenai kebendaan (the reality of things) maupun mengenai orang lain (the reality of others). ${ }^{33}$ Artinya, pengulangan narasi ketertindasan agama secara terus-menerus kepada orang-orang yang memang dijadikan sasaran (supaya merasa menjadi bagian dari kelompok yang menyampaikan narasi itu) dapat ikut membentuk rasa aman ontologis seseorang. Ditambah lagi bila ia hidup di dalam realitas yang dibentuk oleh kelompok tersebut; berhadapan dengan orang di luar kelompok, ia menjadi berpotensi melakukan tindakan diskriminatif, sama seperti mereka yang level rasa aman ontologisnya rendah.

Penjelasan serupa juga dapat diterapkan untuk menerangkan kecenderungan responden survei PPIM untuk bersikap radikal dan intoleran terhadap orang non-Islam. Sebagian responden cenderung sudah memiliki penilaian bahwa kondisi ekonomi pada saat survei itu berlangsung, yaitu tahun 2017, sudah parah, terutama dalam hal kesenjangan antara orang kaya dan miskin. Tercatat ada 52,29\% responden yang menilai kondisi ekonomi Indonesia sedang terpuruk. Sementara itu, terkait dengan bidang hukum, 69,80\% responden menilai bahwa penerapan hukum oleh pemerintah dirasakan tidak adil. Dari situ dapat dilihat bahwa sikap radikal dan intoleran diawali dengan diyakininya suatu gambaran akan suatu situasi yang rapuh serta tidak mendukung terbentuknya kepercayaan dasar dan keamanan ontologis. 
Semua penilaian itu dipelihara dengan opini bahwa Islam di Indonesia pada masa kini sedang berada dalam kondisi terzalimi, seperti yang diyakini oleh $62,11 \%$ responden guru dan dosen, serta 55,08\% responden siswa dan mahasiswa. Selain disebarkan melalui media sosial, opini "agama terzalimi" itu juga dipertahankan dalam berbagai aksi. Salah satu contohnya adalah, seperti disebut pula oleh Akhmad, dalam aksi massa 212 melawan Basuki Tjahaja Purnama yang dianggap menista agama ketika menjabat sebagai Gubernur DKI Jakarta pada tahun 2017. Bahkan, peristiwa itu dianggap sebagai kemenangan umat agama tertentu dan menjadi dasar bagi mereka saat ini untuk melawan penindasan serta mengembalikan kejayaan agamanya. ${ }^{34}$

Uraian panjang lebar di atas akhirnya ingin memperjelas beberapa poin temuan pada tahap awal analisis menurut 'lingkaran pastoral' ini. Pertama, terbentuknya kepercayaan dasar dan keamanan ontologis sangatlah berpengaruh pada keputusan seseorang untuk memperlakukan orang lain yang dianggap asing atau berbeda; besar-kecilnya skala kepercayaan dasar berbanding lurus dengan skala keamanan ontologis dan perlakuan seseorang pada orang lain. Semakin besar kepercayaan dasar seseorang, semakin besar kecenderungannya untuk merasa aman dan terjamin, dan semakin jauh pula mereka dari perilaku diskriminatif.

Hal sebaliknya terjadi pada mereka yang mudah merasa terancam karena kepercayaan dasarnya kurang terbentuk dengan baik. Tidak dimuatnya perihal toleransi antaragama di dalam pendidikan agama juga ikut mempengaruhi terhambatnya pembentukan kepercayaan dasar dan keamanan ontologis di dalam diri anak didik. Kurangnya perhatian pada pendidikan toleransi terse- but masih ditambah dengan merebaknya ajaran dan ajakan untuk menolak mereka yang berbeda agama melalui media sosial, sumber pengetahuan dan pendidikan bagi banyak orang selain sekolah formal. Yang juga perlu diwaspadai adalah faktor-faktor yang sama-tidak adanya pendidikan toleransi, merebaknya narasi anti-pemeluk agama lain-juga dapat menumbuhkan perilaku intoleran di dalam diri mereka yang merasa aman secara ontologis, namun rasa amannya itu dibentuk oleh narasi dan realitas tentang intoleransi.

Kedua, di ranah masyarakat umum, penolakan atas keberagaman juga terjadi dalam bentuk kekerasan terhadap umat beragama lain. Ada pula gerakan untuk mengganti ideologi bangsa. Di balik fenomena tersebut, ada motif untuk menguasai hajat hidup masyarakat, terutama dalam hal ekonomi dan politik. Keinginan untuk berkuasa tanpa pembentukan kepercayaan dasar dan keamanan ontologis kemudian menjadikan seseorang memandang sesamanya sebagai ancaman. Selain itu, kurang tampaknya peran lembaga, baik pemerintah maupun keagamaan, dalam menyikapi intoleransi ikut menyuburkan penolakan atas keberagaman agama di tengah masyarakat.

Pada tahap ini, Giddens telah membantu dalam menemukan akar sosiologis dan psikologis dari pandangan dan perilaku orang mengenai keberagaman, yang terekam pada tahap sebelumnya. Akan tetapi, rupanya penemuan akar sosiologis dan psikologis itu belumlah cukup untuk merefleksikan soal penerimaan masyarakat atas keberagaman, terutama keberagaman agama. Untuk konteks Indonesia, persoalan kepercayaan dasar dan keamanan ontologis diselubungi dengan ajaran teologis. Doktrin dan ayat-ayat Kitab Suci tertentu dari suatu agama diajukan 
sebagai alasan utama tindakan intoleransi. Bagi orang-orang ini, tidaklah cukup menganggap kehadiran seseorang yang dianggap berbeda sebagai ancaman; segala ancaman tersebut bahkan harus disingkirkan karena, menurut mereka, Tuhan yang mereka imani menghendaki demikian. Ada kecenderungan bahwa persoalan tidak terbentuknya kepercayaan dasar dan keamanan ontologis juga mempengaruhi iman dan cara beriman mereka sebagai umat beragama. Demikian pula, pengaruh terhadap iman dan cara beriman juga muncul di dalam diri mereka yang kepercayaan dasar dan keamanan ontologisnya sudah dibentuk oleh narasi dan realitas intoleransi.

Oleh karena itu, pada langkah selanjutnya ingin dilihat hubungan antara kepercayaan dasar dan keamanan ontologis dengan hidup iman seseorang dalam kerangka fenomena keberagaman agama di Indonesia saat ini. Terkait dengan hidup bermasyarakat, ajaran agama dan hidup beriman yang berbeda-beda sesungguhnya tidak dimaksudkan untuk memecah-belah dan menyelubungi motif-motif lain, tetapi ditujukan untuk mencapai cita-cita yang sama. Fenomena bahwa motif dan penyebab non-teologis di dalam penolakan atas keberagaman agama di tengah masyarakat kerap diselubungi atau dikaitkan dengan ajaran agama menjadi titik pijak penulis untuk masuk ke dalam gagasan Agustinus dan Carlo Maria Martini. Kedua tokoh itu membantu studi ini untuk menemukan paham iman dan cara beriman, yang ternyata seharusnya memperkokoh keharmonisan dalam keberagaman masyarakat.

\section{Refleksi Teologis: Kedamaian dalam Hidup Beriman yang Benar}

Hidup beriman ternyata tidak dapat dipisahkan dari hidup bermasyarakat di Indone- sia. Telah ditunjukkan sebelumnya, antara lain, bahwa pendidikan agama untuk konteks Indonesia sejatinya tidak dapat dipisahkan dari pendidikan toleransi. Selanjutnya, masyarakat yang sejak awal tidak dididik dan dibiasakan hidup di dalam keberagaman ternyata tidak memiliki level kepercayaan dasar dan keamanan ontologis yang cukup, atau sudah merasa aman dengan dirinya yang memusuhi orang-orang di luar kelompok agamanya. Akibatnya, kekerasan terjadi dan dihubungkan dengan perbedaan di dalam masyarakat, antara lain perbedaan keyakinan religius.

Hidup beriman dalam konteks Indonesia tidak dapat dipisahkan dari dalil-dalil agama. Giddens menunjukkan bahwa agama dengan berbagai ajarannya telah menjadi lembaga otoritatif di dalam hidup manusia, baik di dalam masyarakat tradisional maupun modern. ${ }^{35}$ Ajaran agama melingkupi berbagai bidang hidup masyarakat, termasuk juga ekonomi dan politik, walaupun tidak menjadi otoritas satu-satunya. Karena cakupannya yang menyeluruh itu, ajaran agama pun dapat ikut mengatur cara penganutnya memenuhi kebutuhan ekonomis dan praktik pelaksanaan kekuasaan di tengah masyarakat. Ketika manusia modern, termasuk di Indonesia, berhadapan dengan ketidakpastian (uncertainty), seperti dipaparkan Giddens, ajaran agama beserta penyampaian oleh para pemimpinnya, menjadi salah satu yang dilirik sebagai pemberi kepastian (conviction).

Mengingat besarnya cakupan otoritas suatu agama dan ajarannya di dalam hidup manusia, termasuk dalam hal politik dan ekonomi, beserta pentingnya peran pemegang otoritas-dalam hal ini pemimpin agama-gesekan di antara yang merasa memiliki otoritas dapat menimbulkan 
persoalan di tengah masyarakat. Persoalan itu dapat muncul, apalagi bila menyadari bahwa sebagian orang Indonesia cenderung mencampuradukkan praktik-dalam istilah Giddens-“beriman" (faith) dengan "tunduknya diri pada otoritas keagamaan" (taking refuge in a dominant authority). ${ }^{36}$ Bagi Giddens, sementara tindakan beriman dilakukan atas dasar kepercayaan (kepada Tuhan), tunduknya diri kepada otoritas keagamaan merupakan sebentuk penyerahan kebebasan dan kemampuan untuk memberi penilaian secara kritis (critical judgment) oleh mereka yang merasakan kebebasan sebagai beban dan penyebab timbulnya ketidakpastian. Persoalan akan muncul ketika pemegang otoritas justru mendorong mereka yang tunduk di bawah otoritas mereka itu untuk membenci orang-orang yang dianggap musuh, lalu mengajarkannya sebagai suatu ungkapan iman.

Oleh karena itu, pada tahap refleksi teologis ini, penulis bermaksud menjernihkan kerancuan ini. Bagi penulis, tindakan iman akan menuntun pada terlaksananya apa yang dicita-citakan oleh Tuhan bagi umat manusia. Sementara itu, penyerahan diri belaka terhadap otoritas agama dengan menghilangkan aspek kebebasan dan berpikir kritis akan menuntun pada pemenuhan agenda pribadi para pemegang otoritas tersebut; praktik yang ini dapat menggagalkan manusia untuk mengenali kehendak dan cara-cara Tuhan. Dengan demikian, ketika agenda pribadi dapat disusupkan dengan bungkus ajaran agama, dialog lintas iman yang sejati tidak akan menghasilkan buah yang tepat walaupun dilaksanakan berulang kali dengan bentuk yang beraneka ragam.

Agustinus dan Martini memberi sumbangan berharga untuk menjernihkan kerancuan tersebut. Seperti akan ditunjukkan berikut ini, titik temu pertama antara pemikiran Agustinus dan Martini adalah ajaran teologis, bagi kedua tokoh ini, mengarah pada terciptanya kedamaian bagi manusia karena Tuhan yang bersabda di dalam ajaran itu adalah Allah yang mengasihi dan menghargai keberagaman. Artinya, Tuhan sendiri mencita-citakan kedamaian dan tersebarnya cinta kasih. Implikasinya adalah menggunakan ajaran-ajaran teologis di dalam suatu narasi dan penanaman nilai untuk melegitimasi kekerasan dan ancaman bukanlah jalan beriman Agustinus dan Martini.

Sementara itu, titik temu kedua antara kedua tokoh ini, yang juga akan dijelaskan selanjutnya, adalah pewarisan nilai mengenai Allah yang mengasihi sangatlah penting dan menuntut keterlibatan banyak pihak. Hal itu berarti, berdasarkan gagasan Agustinus dan Martini, ajaran teologis tidak dapat digunakan untuk membenarkan absennya penanaman nilai-nilai toleransi di dalam pendidikan agama. Doktrin agama juga tidak dapat dimanfaatkan untuk membenarkan sikap diam dan pembiaran berbagai pihak, terutama penyelenggara negara dan lembaga keagamaan, terhadap tindakan intoleran.

Harus diakui bahwa pada zaman Agustinus, pihak Kristiani juga ikut menjadi pelaku intoleransi terhadap keyakinan lain, termasuk agama pagan. Ada 'Masa Kristiani' (Tempora Christiana) yang menandai berkembangnya agama Kristiani sebagai agama resmi Kekaisaran Romawi sejak masa Kaisar Konstantinus. Perkembangan ini terjadi secara khusus pada akhir abad IV. ${ }^{37}$ Dalam istilah lain, inilah masa kristenisasi Kekaisaran Romawi. R. A. Markus menyebut masa ini sebagai masa yang menandai "periode penindasan paganisme secara legal". ${ }^{38}$

Menurut gagasan Agustinus, untuk keluar dari konflik antarkeyakinan, mereka 
yang bukan Kristiani harus memeluk ajaran agama yang dianggapnya benar, yaitu ajaran Kristiani. Merangkul kaum pagan bagi Agustinus berarti mengembalikan mereka ke jalan iman Kristiani. Survei PPIM pada bagian sebelumnya kemudian membuktikan bahwa cara berpikir serupa rupanya juga dihidupkan oleh sebagian orang masa kini dengan memandang penyimpangan dan upaya pindah agama (murtad) sebagai suatu hal yang tidak perlu dilindungi dan, bahkan, dapat diperangi.

Sikap eksklusif memang menjiwai $\mathrm{De} C \mathrm{C}$ vitate Dei. Akan tetapi, yang ingin ditunjukkan di dalam tulisan ini adalah sikap eksklusif Agustinus tersebut tidak lantas meniadakan relevansi gagasannya bagi penerimaan atas keberagaman agama. Alasan penulis adalah ketika sudah masuk ke dalam tataran teologis-dengan melibatkan nama Tuhan di sana-tindakan seseorang akan dikaitkan sekurang-kurangnya dengan dua hal, yaitu "konsep Tuhan seperti apa yang aku imani?" dan "bagaimana memelihara relasiku dengan Tuhan yang kuimani itu?"

Di balik sikap eksklusifnya, Agustinus ingin mengedepankan ajaran mengenai Allah yang mengasihi dan memperhatikan hidup moral setiap orang. Agustinus antara lain menulis demikian di dalam De Civitate Dei:

Dan mereka tentunya harus menganggapnya berasal dari masa Kristiani bahwa, berlawanan dengan kebiasaan perang, kaum barbar yang kejam melepaskan mereka sama sekali di manapun demi nama Kristus-tempat-tempat yang luas, yang dipilih untuk menampung sejumlah besar orang, sehingga belas kasih dapat disebarkan secara lebih luas. ${ }^{39}$

Kutipan tersebut pada dasarnya ingin menunjukkan bahwa gagasan religius De
Civitate Dei masih berupaya menghormati kemanusiaan orang lain, walaupun ia adalah salah satu dari kaum pagan yang belum mengimani Kristus. Untuk memahami kutipan tersebut, sekali lagi perlu dilihat bahwa masa Kristiani pada zaman Agustinus dialami oleh sebagian orang Roma penganut paganisme sebagai masa ketika mereka dijauhkan dari dewa-dewi oleh ajaran asing bernama 'ajaran Kristiani'. Akan tetapi, dengan menuliskan kutipan tersebut, Agustinus mengingatkan bahwa justru pada masa Kristiani pula-masa yang dianggap kejam bagi kaum pagan di Roma-nyawa mereka diselamatkan oleh Allah yang diimani umat Kristiani; sementara di dalam peperangan umumnya orang-orang dapat membunuh sesamanya, di dalam serangan kaum Visigoth ke Roma, mereka tidak membunuh siapapun-termasuk kaum pagan-yang berlindung di gereja, tempat orang-orang Kristiani menyembah Allah mereka. Dengan kata lain, walaupun belum mengimani Kristus, nyawa orang-orang pagan itu terselamatkan karena diizinkan untuk berlindung di bawah naungan gereja dan perlindungan orang-orang Kristiani.

Bagi Agustinus dalam De Civitate Dei, Allah mengajarkan moral kepada umatNya, yaitu Gereja. Dengan menghidupi ajaran moral itu dalam keseharian, yang juga mencakup praktik mengasihi orang lain, Gereja mengenal dan mencintai Allah yang mengasihi. Meminjam ungkapan Giddens, kepercayaan dasar dan keamanan ontologis terbentuk ketika manusia sungguh mengimani Tuhan yang mengasihi sehingga kemudian dapat membagi kasih itu kepada siapapun. Sementara itu, hidup yang lebih mencerminkan cinta diri dan penolakan terhadap orang lain menggambarkan Tuhan (dewa-dewi) yang tidak peduli pada umatnya, serta tidak memberi contoh hidup yang baik kepada mereka. Tuhan yang disebut 
terakhir ini bagi Agustinus bukanlah Allah yang benar dan sejati. ${ }^{40}$

Bagi Agustinus, arah hidup manusia bukanlah pengembalian kejayaan agama seperti yang disebarluaskan di dalam narasi-narasi keagamaan tertentu pada masa kini. Melalui agama, hidup manusia seharusnya terarah pada 'kedamaian' (peace). Yang pada akhirnya dicita-citakan dari pengenalan akan Allah yang benar, relasi yang erat dengan-Nya, dan praktik konkret moral Kristiani beserta penghormatan akan kemanusiaan adalah kedamaian. Ketika dijadikan sebagai suatu cita-cita, pengembalian kejayaan agama berpotensi melegalkan caracara kekerasan, seperti yang dialami oleh umat beragama minoritas, yang diceritakan Romo Endra dan Akhmad pada bagian sebelumnya. ${ }^{41}$ Sementara itu, kedamaian, seperti yang didambakan oleh Agustinus, tidak menghalalkan kekerasan.

Pada bab XI buku XIX De Civitate Dei, Agustinus memaparkan suatu gagasan teologis mengenai 'kedamaian' dan pengaruhnya bagi 'kota Allah' (civitas Dei) dan 'kota duniawi' (civitas terrena). Konsep 'kedamaian' dalam gagasan Agustinus tersebut perlu dibedakan dalam dua pengertian, yaitu pengertian 'eskatologis' dan pengertian 'termanifestasi dalam dunia'. ${ }^{42}$

Pengertian 'eskatologis' ingin memperlihatkan 'kedamaian' sebagai pemenuhan atas realitas temporal yang diciptakan Allah dalam dunia, termasuk waktu itu sendiri. Pengertian 'termanifestasi dalam dunia' ingin menunjukkan 'kedamaian' sebagai situasi sekaligus buah yang dihasilkan melalui penggunaan sarana-sarana duniawi, yang kelak disempurnakan dalam kehidupan abadi. Seperti yang dikatakan oleh Agustinus sendiri, kedamaian adalah "tujuan dari segala kebaikan". ${ }^{43}$ Tujuan akhir dari "kota Allah' adalah "kedamaian dalam hidup kekal" (peace in life everlasting) atau "hidup dalam kedamaian kekal" (life in everlasting peace), sedangkan segala sesuatu (termasuk kedamaian) dalam 'kota duniawi' belumlah sempurna.

Menurut D. J. Billy, konsep kedamaian baik dalam pengertian 'eskatologis' maupun 'termanifestasi dalam dunia' disatukan oleh elemen yang sama. Elemen yang dimaksud adalah "kerinduan instingtif seluruh ciptaan akan kepastian tatanan (the tranquility of order), yang di dalamnya setiap hal memiliki tempatnya masing-masing". ${ }^{44}$ Tatanan (order) dalam pengertian Agustinus berarti "penataan hal-hal yang setara dan tidak setara dalam suatu pola yang ditetapkan kepada hal-hal tersebut sesuai dengan posisinya masing-masing." 'Kedamaian' yang dipikirkan oleh Agustinus, dalam pengertian Billy, kemudian dihidupi di setiap level eksistensi manusia; beberapa dari level itu ditunjukkan di dalam tabel ini. ${ }^{45}$

Tabel 1. 'Kedamaian' dalam beberapa level eksistensi manusia.

\begin{tabular}{|c|l|}
\hline Level Eksistensi & \multicolumn{1}{c|}{ Wujud 'Damai' } \\
\hline $\begin{array}{l}\text { 1. Tubuh dan jiwa (body } \\
\text { and soul) }\end{array}$ & $\begin{array}{l}\text { Keteraturan sebagaimana mestinya terjadi antara } \\
\text { hidup dan kesehatan makhluk hidup (the duly or- } \\
\text { dered life and health of a living creature). }\end{array}$ \\
\hline
\end{tabular}




\begin{tabular}{|l|l|}
\hline $\begin{array}{l}\text { 2. Antara manusia fana } \\
\text { dan Allah (mortal } \\
\text { man and God) }\end{array}$ & $\begin{array}{l}\text { Suatu ketaatan teratur dalam iman, dalam penye- } \\
\text { rahan diri kepada suatu hukum yang kekal (an or- } \\
\text { dered obedience, in faith, in subjection to an ever- } \\
\text { lasting law). }\end{array}$ \\
\hline $\begin{array}{l}\text { 3. Antarmanusia (be- } \\
\text { tween men) }\end{array}$ & $\begin{array}{l}\text { Suatu kesepahaman yang teratur dari pikiran de- } \\
\text { ngan pikiran (an ordered agreement of mind with } \\
\text { mind). }\end{array}$ \\
\hline $\begin{array}{l}\text { 4. Kota (city) } \\
\text { Suatu kesepahaman yang teratur dari para war- } \\
\text { ga kota dengan penghormatan pada wibawa dan } \\
\text { kepatuhan (an ordered agreement of the citizens } \\
\text { with respect to commanding and obeying). }\end{array}$ \\
\hline $\begin{array}{l}\text { (Heavenly city) } \\
\text { (whole universe) }\end{array}$ & $\begin{array}{l}\text { Suatu persahabatan yang sempurna tertata dan } \\
\text { harmonis dalam sukacita Allah, dan suatu persa- } \\
\text { habatan timbal balik dalam Allah (a perfectly or- } \\
\text { dered and perfectly harmonious fellowship in the } \\
\text { enjoyment of God, and a mutual fellowship in } \\
\text { God). }\end{array}$ \\
\hline
\end{tabular}

Jadi, yang sebenarnya diharapkan dapat lebih dulu terjadi saat ini di manapun, termasuk di Indonesia, adalah suatu kedamaian 'termanifestasi dalam dunia', yaitu suatu kepastian tatanan di dalam diri manusia itu sendiri, antarmanusia, antara manusia dan Allah, hingga seluruh semesta. Kedamaian itulah yang akan disempurnakan kelak di dalam kehidupan kekal. Agustinus menggagas konsep 'kota Allah', yang di dalamnya kedamaian hidup di dunia menjadi sempurna di dalam kehidupan surgawi. Dengan kata lain, berdasarkan gagasan Agustinus, tidaklah mungkin mengharapkan suatu kedamaian sempurna di dalam kehidupan kekal tanpa lebih dulu mengupayakannya di dunia.

Bukan hanya di zaman Agustinus, cita-cita akan kedamaian masih tetap ada hingga zaman modern, seperti ditampilkan melalui gagasan Martini di dalam tulisan ini. Sebagaimana Agustinus mencita-citakan kedamaian abadi sebagai muara dari segala kebaikan, Martini menekankan bahwa kedamaian itu merupakan "tujuan dan sasaran sejati bangsa manusia" (the true end and aim of the human race). ${ }^{46}$ Sejalan dengan Agustinus, ia juga menyebutkan tiga tataran kedamaian, yaitu kedamaian di dalam diri individu (within the individual), di antara orang beriman (among the faithful), dan universal (universal peace). ${ }^{47}$ Bahkan, mengikuti Agustinus, Martini juga menyebut kedamaian sebagai suatu "kepastian tatanan" (the tranquility of order). ${ }^{48}$

Bagi Martini, yang menjadi penting adalah kedamaian inilah yang menjadi alasan manusia berusaha menjunjung tinggi nilainilai kemanusiaan. ${ }^{49}$ Ia juga menunjukkan bahwa, baginya, kedamaian dan menjunjung tinggi nilai kemanusiaan paling konkret di- 
wujudkan dengan menerima orang lain, apapun latar belakangnya. Tidak ada lagi orang lain yang diperlakukan sebagai orang asing (stranger), baik itu karena suku, ras, maupun agamanya.

Sejalan dengan Agustinus, Martini juga mengakui bahwa cara seseorang mengimani Allah berpengaruh pada caranya memperlakukan orang lain, terutama yang berbeda darinya. Ia mengatakan bahwa "pandangan seseorang terhadap orang yang dianggap asing bergantung pada konsepnya tentang Allah (the estimate of the stranger is dependent on the concept of God)". ${ }^{50}$ Oleh karena itu, cara seseorang memahami dan menafsirkan ajaran agama dan relasinya dengan Tuhan menjadi penting untuk digarap agar ia sungguh mengimani Tuhan yang benar.

Martini sendiri sudah memberi contoh melalui penemuannya sesuai tradisi Kristiani yang ia anut. Sesuai penafsiran Martini, kedamaian di dalam masyarakat dapat dicapai ketika orang yang dianggap asing di suatu tempat diperlakukan sama seperti orang yang sudah lama hidup di sana. 'Orang-orang asing' (strangers) disebut di dalam Perjanjian Lama menggunakan kata Ibrani 'ger' (רג), yang sebenarnya berarti 'hidup' (live).

'Ger' dapat dipakai berdampingan dengan kata 'toshav' (ger toshav, רג בשות) dan diartikan sebagai 'penduduk' atau 'pemukim' (resident, inhabitant). 'Toshav' sendiri berarti 'penduduk' dalam arti yang lebih umum. ${ }^{51}$ Istilah ini juga disematkan pada bangsa Israel, misalnya dalam Kej 15:13, yaitu ketika Allah bernubuat kepada Abraham bahwa pada suatu masa Israel akan mengalami keadaan sebagai orang asing di tempat yang bukan milik mereka sendiri. ${ }^{52}$ Bila dibandingkan dengan pengalaman bangsa Israel tersebut, kata 'ger toshav' itu dapat diarti- kan sebagai "orang asing yang telah tinggal di Israel dalam waktu lama” sehingga telah memiliki keturunan di sana. ${ }^{53}$ Hukum Perjanjian Lama, misalnya Kel 22:21 dan Ul 10:19, sendiri mengharuskan bangsa Israel untuk menghormati ger dan tidak menindas mereka karena bangsa Israel pun pernah menjadi ger di Mesir.

Ketika mengungkapkan gagasan tersebut, secara jelas Martini membayangkan Eropa dan Gereja yang membuka pintu bagi para imigran atau pengungsi. Yang dianggap 'asing' sudah jelas, yaitu para imigran dan pengungsi. Penjelasannya kemudian mengambil pendasaran dari pengalaman bangsa Israel, yang mirip dengan pengalaman Eropa pada zaman Martini.

Untuk konteks Indonesia, tetap harus disadari bahwa fenomena ke-asing-an antara konteks Martini dan Indonesia memang dapat berbeda. Sebagai contoh, yang kerap terjadi adalah agama 'pendatang'agama-agama besar seperti Islam dan Kristiani-menganggap asing apa yang merupakan keyakinan asali orang-orang Indonesia. Menjadikan agama-agama asli sebagai agama asing seperti itu rupanya berdampak pada mereka yang menganutnya; walaupun para penganutnya adalah penduduk asli suatu daerah, mereka dapat dianggap asing karena tidak memeluk agama yang dianut dan diakui di Indonesia, terutama yang dianut oleh mayoritas penduduk.

Pada dasarnya memang tidak ada warga Indonesia yang sungguh-sungguh merupakan 'ger'. Oleh karena itu, seharusnya memang tidak ada orang yang dipandang atau memandang sebagai 'asing' di Indonesia. Akan tetapi, nyatanya praktik 'peng-asingan' terjadi seperti yang telah dipaparkan. Gagasan Martini lantas menjadi relevan untuk memperbarui pandangan masyarakat 
modern; seperti yang telah dipaparkan, bagi Martini, kedamaian sejati mengandaikan semakin berkurangnya 'peng-asing-an' sampai lenyap sama sekali.

Data dari dokumen, survei, dan wawancara pada tahap sebelumnya memperlihatkan bahwa tidaklah mudah bagi masyarakat di Indonesia untuk memenuhi cita-cita Agustinus dan Martini. Ditemukannya inkonsistensi di dalam hasil-hasil survei memperlihatkan pergulatan masyarakat Indonesia ketika memperlakukan orang lain sebagai sesama di Indonesia, khususnya dengan tetap mengakui perbedaan latar belakang religius. Sebagai contoh, walaupun di satu sisi cukup banyak responden yang tidak memusuhi mereka yang berbeda agama, ternyata di sisi lain ada juga yang tidak menyetujui perlindungan terhadap umat suatu agama yang dianggap sesat. Contoh lain, dari agama yang sama-dengan ajaran iman yang sama-ada kelompok yang melakukan tindak kekerasan dan pengasing-an terhadap umat beragama lain, tapi ada pula yang justru membantu mereka yang menjadi korban kebencian atas nama agama tersebut, seperti dilakukan oleh Akhmad dan Jaringan Gusdurian.

Agustinus membaca fenomena semacam itu sebagai akibat dari percampuran antara 'kota Allah' dan 'kota duniawi' di dalam kehidupan saat ini. 'Kota Allah' yang dibangun atas dasar cinta kasih dari Allah masih dapat disusupi oleh hasrat akan kekuasaan yang membentuk 'kota duniawi'. ${ }^{54}$ Sementara itu, Martini melihat fenomena tersebut sebagai bagian dari kerapuhan tatanan dunia yang masih harus terus-menerus diperbaiki. ${ }^{55}$

Baik Agustinus maupun Martini memperlihatkan bahwa ada kerinduan akan kedamaian sejati; masyarakat Indonesia yang bergulat dalam menerima keberagaman agama pun sejatinya mengalami kerinduan yang sama. Oleh karena kerinduan yang sama itu, memang tidak seharusnya ajaran agama menjadi sarana pemecah belah di dalam masyarakat; perpecahan dan penolakan justru bertentangan dengan kedamaian yang dicita-citakan itu. Martini bahkan dengan optimis mengatakan bahwa agama merupakan percikan cahaya (spark of light), yang "memurnikan bumi (purify the earth), meringankannya (lighten it), membuatnya manis (sweeten it), menjadikannya tempat hidup (make it a place to live in), serta memberi harapan dan kekuatan (give hope and strength) bagi mereka yang cemas, takut, dan dilanda persoalan (those whose faces are drawn with anguish, fear and strife)" ${ }^{56}$

\section{Perencanaan Pastoral: Pendidikan, Keterlibatan, Integrasi}

Pada tahap ini, penulis menerjemahkan gagasan yang diilhami Agustinus dan Martini ke dalam beberapa langkah pastoral berikut. 


\begin{tabular}{|c|c|c|c|}
\hline No. & $\begin{array}{c}\text { Pokok Gagasan } \\
\text { Agustinus }\end{array}$ & $\begin{array}{c}\text { Pokok Gagasan } \\
\text { Martini }\end{array}$ & $\begin{array}{c}\text { Integrasi Langkah } \\
\text { Pastoral } \\
\end{array}$ \\
\hline 1. & $\begin{array}{l}\text { Pengenalan akan Allah } \\
\text { yang benar, yaitu Al- } \\
\text { lah yang mengasihi dan } \\
\text { mengajari umat-Nya un- } \\
\text { tuk mengasihi. }\end{array}$ & $\begin{array}{l}\text { Pandangan seseorang } \\
\text { terhadap orang yang } \\
\text { dianggap asing bergan- } \\
\text { tung pada konsepnya } \\
\text { tentang Allah. }\end{array}$ & $\begin{array}{l}\text { Menyusun kurikulum dan pan- } \\
\text { duan pendidikan Agama Katolik } \\
\text { yang memuat: } \\
\text { 1) pengajaran pokok iman Katolik; } \\
\text { 2) tindakan kasih konkret dan } \\
\text { lintas iman sebagai salah satu } \\
\text { komponen penilaian. } \\
\text { Kurikulum ini berlaku bukan ha- } \\
\text { nya di sekolah, melainkan juga di } \\
\text { gereja dan keluarga. }\end{array}$ \\
\hline 2. & $\begin{array}{l}\text { Pendidikan sebagai tindak- } \\
\text { an pewarisan. }\end{array}$ & $\begin{array}{l}\text { Pendidikan sebagai tin- } \\
\text { dakan pewarisan dan } \\
\text { penerusan. }\end{array}$ & $\begin{array}{l}\text { Membangun dan menyebarkan } \\
\text { narasi mengenai Tuhan dan hidup } \\
\text { beriman yang mendukung pene- } \\
\text { rimaan akan keberagaman, baik } \\
\text { melalui pelajaran agama di seko- } \\
\text { lah, tafsir, khotbah, pendalaman } \\
\text { iman, dan media sosial. }\end{array}$ \\
\hline 3. & $\begin{array}{l}\text { Menjaga pikiran manusia } \\
\text { dari hal-hal selain Allah } \\
\text { sendiri. }\end{array}$ & $\begin{array}{l}\text { a. Menanamkan dan } \\
\text { menyebarkan nilai- } \\
\text { nilai kemanusiaan } \\
\text { yang mendukung } \\
\text { kesatuan, kebera- } \\
\text { gaman, kebebasan, } \\
\text { dll. }\end{array}$ & $\begin{array}{l}\text { Mendukung dan menganjurkan } \\
\text { keterlibatan umat, mulai dari anak- } \\
\text { anak sampai orang dewasa, di da- } \\
\text { lam perkumpulan lintas iman yang } \\
\text { sejalan dengan visi "mewartakan } \\
\text { Allah yang mengasihi dan mendidik } \\
\text { umat-Nya untuk mengasihi." }\end{array}$ \\
\hline \multirow[t]{2}{*}{4.} & \multirow[t]{2}{*}{$\begin{array}{l}\text { Mempertobatkan mereka } \\
\text { yang hidupnya tidak sesuai } \\
\text { dengan ajaran moral dari } \\
\text { Allah yang benar. }\end{array}$} & \multirow[t]{2}{*}{$\begin{array}{l}\text { b. Pengintegrasian } \\
\text { seseorang ke dalam } \\
\text { masyarakat di seki- } \\
\text { tarnya. }\end{array}$} & $\begin{array}{l}\text { Merancang program bagi peserta } \\
\text { lintas iman untuk tinggal bersama } \\
\text { selama beberapa waktu. }\end{array}$ \\
\hline & & & $\begin{array}{l}\text { Membentuk Komisi KKPKC di } \\
\text { semua paroki dan keuskupan yang } \\
\text { belum memiliki sebagai tim advo- } \\
\text { kasi yang menyuarakan aspirasi } \\
\text { korban tindakan intoleransi. }\end{array}$ \\
\hline
\end{tabular}


Bagi Agustinus dan Martini, kedamaian tidak dapat dipisahkan dari penghormatan seseorang akan yang lain; penghormatan akan yang lain itu sendiri tidak dapat dipisahkan dari relasi seseorang dengan Tuhan dan upaya hariannya menghidupi ajaran-Nya. Dengan kata lain, jika dipahami menurut gagasan mereka, pendidikan agama, baik di sekolah dan perkumpulan umat maupun melalui media sosial, tidak dapat secara berlebihan menekankan pendidikan kesalehan pribadi belaka-seperti ditunjukkan hasil survei-tanpa diimbangi dengan perhatian kepada sesama, termasuk mereka yang berbeda agama.

Pendidikan agama yang sungguh berorientasi pada pembinaan relasi manusia dengan Tuhan yang Mahakasih juga tidak dapat mengeksklusi kelompok-kelompok keagamaan lain seperti yang diperlihatkan banyak responden guru dan sebagian kecil dosen, mahasiswa, dan siswa menurut survei PPIM. Perjumpaan nyata menjembatani jurang ketidaktahuan dan kesalahpahaman antarbudaya atau agama yang berbeda di dalam masyarakat. Jembatan ini dibangun dengan cara membiarkan setiap orang berbicara tentang wawasan mereka dalam bahasa, ungkapan, atau keyakinan mereka sendiri.

Pendidikan agama yang benar juga tidak akan menghasilkan perilaku kekerasan dan teror terhadap umat beragama lain seperti dalam kasus-kasus yang ditangani Romo Endra dan Akhmad. ${ }^{57}$ Alih-alih, pendidikan agama yang benar menghasilkan orangorang seperti Akhmad, yang justru berusaha membantu umat beragama lain yang berada di dalam kesulitan. Pendidikan agama yang benar membantu orang melihat kesesuaian nilai-nilai keagamaan dengan nilai-nilai kebangsaan, yang mendukung terciptanya ke- harmonisan hidup bersama di dalam keberagaman.

Selain perjumpaan, penanaman ajaran, nilai, dan narasi akan iman dan hidup beriman yang benar juga sama pentingnya. Baik kurikulum sekolah, keluarga, maupun media sosial dapat dimanfaatkan sebagai sarananya. Dengan belajar dari pemaparan kasus-kasus pada bagian sebelumnya, salah satu contoh pengajaran itu adalah memaknai ulang ajaran pengampunan dari Yesus supaya tidak meninabobokan umat Katolik saat menghadapi intoleransi; di satu sisi, pengampunan memang perlu sebagai pengamalan ajaran Yesus, tetapi, di sisi lain, juga tetap harus menyuarakan ketidakadilan seperti Yesus sendiri. Meminjam ungkapan Jay Akhmad dan mengombinasikannya dengan gagasan Agustinus, penanaman semacam itu "melawan narasi-narasi yang tidak sejalan dengan Sang Pencipta," yaitu narasi-narasi yang menghambat, menurut istilah Martini, "integrasi manusia ke dalam masyarakat sekitar" $"$.

Cita-cita Agustinus sejalan dengan impian Martini, yaitu Gereja menjadi pelopor konkret terciptanya tatanan kota Allah yang membawa kedamaian di dunia. Pertanyaannya adalah apakah cita-cita itu harus seolah-olah secara eksklusif hanya dimiliki oleh Gereja? Penulis melihat bahwa cita-cita itu tidak identik secara eksklusif dengan Gereja. Meminjam ungkapan Markus, Gereja, bahkan dalam pikiran Agustinus sekalipun, bagaimanapun juga dipandang sebagai suatu organisasi lahiriah dalam masyarakat. ${ }^{59}$ Artinya, jika Gereja mampu memelopori perwujudan cita-cita 'kota Allah', organisasi keagamaan lain juga dapat memperjuangkannya.

Pembentukan Komisi KKPKC atau kelompok advokasi serupa dapat dibaca dalam bingkai pendidikan sekaligus upaya 
memperjuangkan kedamaian di dalam masyarakat luas. Menurut Romo Endra, KKPKC berperan "menularkan keberanian bagi orang awam untuk berani bersuara, berani untuk membangun jejaring dengan orangorang di sekitar, berani untuk menjadi wajah Gereja." ${ }^{00}$ Kelompok ini juga perlu bekerja sama lintas iman dan lintas komunitas, seperti dikatakan Akhmad. "Ini kita harus bareng-bareng bergerak karena Gusdurian sendiri juga memahami nggak bisa selesai di tangan Gusdurian. Ini harus banyak kelompok yang terlibat," ujarnya ${ }^{61}$

Pengalaman merupakan bagian yang tidak terpisahkan dari suatu pendidikan. Demikian pula dengan pengalaman perjumpaan dan kerja sama konkret dengan mereka yang berbeda agama harus menjadi bagian yang terintegrasi dalam pendidikan suatu agama. Ajaran teoretis abstrak tentang keyakinan religius diwujudkan melalui kedalaman dialog antarmanusia yang di dalamnya seseorang mencita-citakan suatu kolaborasi untuk membangun tata hidup bersama yang mendukung kedamaian. Langkah edukasi, seperti yang diilhami lewat pemikiran Agustinus dan Carlo Maria Martini, merupakan bentuk pastoral yang menjadi sumbangan yang penulis tawarkan demi terbentuknya tatanan masyarakat yang menerima keberagaman.

\section{KESIMPULAN}

Realitas keberagaman tidak dapat-dan tidak perlu-ditolak pada zaman ini. Akan tetapi, memang tidaklah mudah membangun kedamaian di dalam masyarakat Indonesia yang beragam bila masyarakatnya masih enggan beradaptasi dan menerima perbedaan. Pertanyaan penulis pada bagian awal tulisan ini, yaitu "mengapa masih terjadi berbagai praktik intoleransi, khususnya dalam hal agama, di Indonesia, walaupun dialog-dialog sudah digencarkan sejak dulu di dalam masyarakat?" sudah terjawab. Jawabannya adalah tersembunyinya agenda-agenda pribadi di balik ajaran agama serta pencampuradukkan ungkapan iman sejati dengan praktik-praktik lainnya menjadi penyebab tidak bermuaranya dialog lintas iman pada kedamaian sejati.

Dengan alasan itulah penulis memandang penting peran Agustinus dan Martini yang menekankan pendidikan untuk menanamkan semangat menyelaraskan iman-bukan penyerahan diri dan akal sehat begitu saja kepada otoritas keagamaandengan hidup moral. Pendidikan membantu membadankan semua itu dalam diri setiap individu. Baik bercorak 'edukasi teologis' seperti ajaran Agustinus maupun 'edukasi dialog-keterlibatan' yang ditawarkan Martini sama-sama memiliki cita-cita kedamaian hidup bersama sebagai muara keselarasan iman dan perbuatan konkret.

Walaupun demikian, tetap perlu disadari bahwa Agustinus dan Martini merupakan pemikir Gereja. Dengan kata lain, pemikiran kedua tokoh ini terikat dengan konteks Gereja yang ingin menanggapi situasi zaman. Oleh karena itu, pelibatan umat beragama lain mengandaikan adanya kekritisan atas perbedaan konteks yang tercipta karena perbedaan zaman, teritori, agama, dan cara pandang.

Sebagai pemikir Gereja, baik Agustinus maupun Martini terutama mendasarkan argumen mereka pada sumber-sumber ajaran iman Kristiani. Seperti yang telah ditunjukkan sebelumnya, dalam konteks pembelaan atas tuduhan kaum pagan Romawi, Agustinus memiliki agenda untuk menunjukkan Tuhan yang benar kepada mereka. Tuhan yang dimaksud adalah Tuhan yang disembah 
menurut ajaran Gereja. Di satu sisi Agustinus memang menunjukkan bahwa ketika ada serangan orang-orang Visigoth, kaum pagan seharusnya berterima kasih karena diperbolehkan berlindung dan menyelamatkan diri di dalam gereja. Di sisi lain, dengan mengedepankan ajaran Gereja, Agustinus juga menunjukkan agama Kristiani sebagai agama yang benar dan merasa superior atas keyakinan religius lainnya.

Martini tidaklah sekeras Agustinus dalam hal menampilkan ajaran Gereja Katolik. Ia menjunjung tinggi inklusivisme. Walaupun demikian, di dalam berbagai sambutan, pidato, dan renungan, Martini kerap menggunakan ungkapan bernuansa Katolik, walaupun dilakukan di hadapan hadirin lintas agama. Risikonya adalah ungkapan itu dapat disalahpahami ketika diucapkan di hadapan komunitas non-Katolik dan justru menghambat relasi lintas agama yang ingin ia bangun.

\section{CATATAN AKHIR}

Pradito Dita Pertana, "Perbedaan Agama Membuat Slamet Ditolak Tinggal di Dusun Karet Bantul”, DetikNews, 2 April 2019, tersedia dari https://news.detik. com/berita-jawa-tengah/d-4494241/perbedaan-agamamembuat-slamet-ditolak-tinggal-di-dusun-karet-bantul; diakses 11 April 2019

Joe Holland dan Peter Henriot, Social Analysis: Linking Faith and Justice, Cetakan keempat, (Maryknoll, NY: Orbis Books, 1986), 7-10. Penerjemahan istilah mengikuti Joe Holland dan Peter Henriot, Analisis Sosial dan Refleksi Teologis: Kaitan Iman dan Keadilan, diterjemahkan oleh B. Herry-Priyono, (Yogyakarta: Kanisius, 1986).

Joe Holland dan Peter Henriot, Social Analysis: Linking Faith and Justice, 8.

4 SETARA Institute, "Laporan Tengah Tahun Kondisi Kebebasan Beragama/Berkeyakinan dan Minoritas Keagamaan di Indonesia 2018” (20 Agustus 2018), tersedia dari http://setara-institute.org/laporan-tengahtahun-kondisi-kebebasan-beragamaberkeyakinan-danminoritas-keagamaan-di-indonesia-2018/; diakses 20 Mei 2019.

5 Social Progress Imperative, "2018 Social Progress Index" (21 September 2018), tersedia dari https://www. socialprogress.org/?tab $=2 \&$ code $=I D N \&$ compare $=I D-$ N\&prop=BHN; diakses 20 Mei 2019. Ada 51 indikator indeks, yang diklasifikasi menjadi tiga indikator besar, yaitu 'Basic Human Needs' (Kebutuhan Dasar Manusia), 'Foundations of Wellbeing' (Dasar-Dasar Kesejahteraan), 'Opportunity' (Peluang). Aspek kebebasan beraga-
Suatu refleksi teologis pada akhirnya tidak dapat dipisahkan dari penafsiran setiap orang terhadap Kitab Suci yang ia imani. Oleh karena itu, cara orang dalam memahami dan mengimani 'Allah yang benar' dan 'cara beriman yang benar' pun dapat berbeda-beda seturut penafsirannya. Para pewaris gagasan Agustinus dan Martini terus ditantang untuk menemukan cara kreatif membahasakan pemikirannya agar dapat dipahami oleh khalayak umum, terutama ketika pembicaraan terkait agama menjadi semakin sensitif seperti di Indonesia saat ini. Selalu ada kemungkinan bahwa pemeluk agama lain tidak akan setuju pada pendasaran agamis seperti yang dilakukan oleh Agustinus dan Martini. Akan tetapi, ketulusan berkomunikasi tetaplah penting dengan mengingat tujuan bersama yang ingin diupayakan bersama, yaitu terciptanya tatanan yang mendukung perdamaian dalam suatu masyarakat yang beragam.

ma dan perlakuan terhadap minoritas termasuk dalam kategori 'Opportunity'.

$6 \quad$ SETARA Institute, "Ringkasan Eksekutif Indeks Kota Toleran Tahun 2018” (7 Desember 2018), tersedia dari https://drive.google.com/file/d/1SR3-7tWpb16QpyyIydHBnm8eLiqEPjHp/view; diakses 21 Mei 2019.

7 SETARA Institute, "Ringkasan Eksekutif Indeks Kota Toleran Tahun 2018”, 2-7.

8 Caroline Damanik, "Kronologi Kasus Meiliana yang Dipenjara karena Keluhkan Pengeras Suara Azan", Kompas.com, 23 Agustus 2018, tersedia dari https:// regional.kompas.com/read/2018/08/23/15053451/kronologi-kasus-meiliana-yang-dipenjara-karena-keluhkan-pengeras-suara-azan; diakses 21 Mei 2019.

9 PPIM UIN Jakarta-UNDP Indonesia, "Sikap dan Perilaku Keberagaman Guru dan Dosen Pendidikan Agama Islam", Convey Report, Vol. 1, No. 9 Th. 2018.

10 PPIM UIN Jakarta-UNDP Indonesia, "Sikap dan Perilaku Keberagaman Guru dan Dosen Pendidikan Agama Islam", 11-12.

11 PPIM UIN Jakarta-UNDP Indonesia, "Sikap dan Perilaku Keberagaman Guru dan Dosen Pendidikan Agama Islam", 11-12.

12 PPIM UIN Jakarta-UNDP Indonesia, "Sikap dan Perilaku Keberagaman Guru dan Dosen Pendidikan Agama Islam", 10.

13 Lembaga Survei Indonesia, Tren Persepsi Publik tentang Demokrasi, Korupsi, dan Intoleransi: Temuan Survei Nasional 1-7 Agustus 2018 (Jakarta: Lembaga Survei Indonesia, 2018).

14 Lembaga Survei Indonesia, Tren Persepsi Publik ten- 
tang Demokrasi, Korupsi, dan Intoleransi, 29-30.

15 Lembaga Survei Indonesia, Tren Persepsi Publik tentang Demokrasi, Korupsi, dan Intoleransi, 39.

16 PPIM UIN Jakarta-UNDP Indonesia, "Sikap dan Perilaku Keberagaman Guru dan Dosen Pendidikan Agama Islam", 12-13.

17 Centre for Strategic and International Studies (CSIS), "3 Tahun Jokowi: Kenaikan Elektoral dan Kepuasan Publik, Laporan Survei," dipresentasikan di Jakarta pada 9 September 2017.

18 Lembaga Survei Indonesia, Tren Persepsi Publik tentang Demokrasi, Korupsi, dan Intoleransi, 31-34

19 Jay Akhmad, "Wawancara dengan Jay Akhmad, Koordinator Sekretariat Nasional (Seknas) Jaringan Gusdurian," wawancara pada tanggal 25 Maret 2019, audio, 60:24, verbatim terlampir.

20 Jay Akhmad, wawancara.

21 F. X. Endra Wijayanto, "Wawancara dengan RD. F. X. Endra Wijayanto,. Koordinator Komisi Karya Keadilan, Perdamaian, dan Keutuhan Ciptaan Keuskupan Agung Semarang (KKPKC-KAS), " wawancara pada tanggal 21 Februari 2019, audio, 60:07, verbatim terlampir.

22 F. X. Endra Wijayanto, wawancara.

23 Jay Akhmad, wawancara.

24 F. X. Endra Wijayanto, wawancara.

25 Anda ini tetap benar. Tidak usah takut. Tetap ada yang menemani ini, santai saja, tidak apa-apa." Jay Akhmad, wawancara.

26 Anthony Giddens, Modernity and Self-Identity: Self and Society in the Late Modern Age, (Cambridge, UK: Polity Press, 1991), 36-42.

27 Dibahasakan ulang dari pemaparan Giddens dalam Anthony Giddens, Modernity and Self-Identity: Self and Society in the Late Modern Age, 38-40. Istilah 'kepercayaan dasar' Giddens ambil dari ahli psikososial, Erik Erikson.

28 Anthony Giddens, Modernity and Self-Identity: Self and Society in the Late Modern Age, 37.

29 Anthony Giddens, Modernity and Self-Identity: Self and Society in the Late Modern Age, 40.

30 Anthony Giddens, Modernity and Self-Identity: Self and Society in the Late Modern Age, 43-44. Giddens, dengan menggunakan gagasan Sigmund Freud, lebih lanjut membedakan 'kecemasan' (anxiety) dari 'ketakutan' (fear); sementara 'ketakutan' memiliki objek, 'kecemasan' muncul dari diri sendiri dan tanpa objek tertentu.

31 Anthony Giddens, Modernity and Self-Identity: Self and Society in the Late Modern Age, 40-41.

32 Anthony Giddens, Modernity and Self-Identity: Self and Society in the Late Modern Age, 41.

33 Anthony Giddens, Modernity and Self-Identity: Self and Society in the Late Modern Age, 53-55.

34 Jay Akhmad, wawancara.

35 Anthony Giddens, Modernity and Self-Identity: Self and Society in the Late Modern Age, 194-196.

36 Anthony Giddens, Modernity and Self-Identity: Self and Society in the Late Modern Age, 196.

37 Kata pengantar William Babcock dalam Augustine, The City of God (De Civitate Dei) I-X, x. Lih. pula R. A
Markus, Saeculum: History and Society in the Theology of St. Augustine, (Cambridge: Cambridge University Press, 1970), 22-44.

38 R. A. Markus, Saeculum: History and Society in the Theology of St. Augustine, 35.

39 And they certainly ought to ascribe it to these Christian times that, contrary to the usages of war, the cruel barbarians spared them anywhere at all for the sake of Christ's name-vast places, chosen to hold huge throngs, so that mercy might be spread more widely. Civ. Dei I.1. Bdk. Juga dengan pemaparan Agustinus dalam, antara lain, II.4-7.

40 Lih. antara lain Civ. Dei II.4-7.

41 F. X. Endra Wijayanto, wawancara.

42 D. J. Billy, “The Analogy of 'Peace' in Augustine's City of God", Studia Moralia 32, No. 2 (1994), 317.

43 Civ. Dei XIX.11.

44 D. J. Billy, "The Analogy of 'Peace' in Augustine's City of God", 318. Bdk. Civ. Dei XIX.13.

45 Civ. Dei XIX.13.

46 Carlo M. Martini,"Peoples on Earth, Prayers to God: Milan and the Prayer for Peace," 35.

47 Carlo M. Martini,"Prayer at the Root of Peace," 18.

48 Carlo M. Martini,"Prayer at the Root of Peace," 20.

49 Carlo M. Martini,"Peoples on Earth, Prayers to God," 35.

50 Carlo M. Martini, "The Church and A Multiracial Society" dalam Carlo M. Martini, The Dove at Rest, diterjemahkan dari Il Riposo della Colomba, oleh D. Mary Groves, (Kildare, Irlandia: St. Pauls, 1995), 82

51 Dalam bahasa Inggris, kata 'toshav' dapat diterjemahkan sebagai 'resident', 'inhabitant', atau bahkan 'native'.

52 Demikian kutipannya, "Firman TUHAN kepada Abram: "Ketahuilah dengan sesungguhnya bahwa keturunanmu akan menjadi orang asing dalam suatu negeri, yang bukan kepunyaan mereka, dan bahwa mereka akan diperbudak dan dianiaya, empat ratus tahun lamanya" (cetak miring oleh penulis).

53 Carlo M. Martini, "The Church and A Multiracial Society," 81-82.

54 Remember, however, that among those very enemies are hidden some who will become citizens, and do not think it fruitless to bear their enmity until they come to confess the faith. By the same token, [...], the city of God has with it, [...], some from the number of its enemies who will not be with it in the eternal destiny of the saints. Demikian tulis Agustinus dalam Civ. Dei I.35.

55 Martini, "The Dove At Rest," 43.

56 Martini, "The Dove At Rest," 43.

57 F. X. Endra Wijayanto dan Jay Akhmad, wawancara.

58 Jay Akhmad, wawancara. Jay Akhmad menekankan bahwa narasi-narasi yang mendukung toleransi digencarkan untuk melawan narasi-narasi intoleran. Walaupun bernada negatif, gagasan tersebut kiranya masih sejalan dengan ajaran baik Agustinus maupun Martini.

59 R. A. Markus, Saeculum: History and Society in the Theology of St. Augustine, 119.

60 F. X. Endra Wijayanto, wawancara

61 Jay Akhmad, wawancara. 


\section{DAFTAR RUJUKAN}

, Alkitab Deuterokanonika, Jakarta: Lembaga Alkitab Indonesia, 1974 (Teks Deuterokanika oleh Lembaga Biblika Indonesia, 1976).

Augustine. The City of God (De Civitate Dei) I-X, terj. William Babcock, New York: New City Press, 2012.

The City of God (De Civitate Dei) XI-XXXII, terj. William Babcock, New York: New City Press, 2013.

Billy, D. J. "The Analogy of 'Peace' in Augustine's City of God", Studia Moralia 32, No. 2 (1994), 317-339.

Centre for Strategic and International Studies (CSIS). "3 Tahun Jokowi: Kenaikan Elektoral dan Kepuasan Publik, Laporan Survei," dipresentasikan di Jakarta pada 9 September 2017.

Damanik, Caroline. "Kronologi Kasus Meiliana yang Dipenjara karena Keluhkan Pengeras Suara Azan", Kompas.com, 23 Agustus 2018, tersedia dari https://regional.kompas.com/read/2018/08/23/15053451/ kronologi-kasus-meiliana-yang-dipenjara-karena-keluhkan-pengeras-suara-azan; diakses 21 Mei 2019.

Giddens, Anthony. Modernity and Self-Identity: Self and Society in the Late Modern Age, Cambridge, UK: Polity Press, 1991.

Held, David et al. "Globalization". Global Governance, Vol. 5, Th. 1999, No. 4, 483-496.

Holland, Joe dan Peter Henriot. Social Analysis: Linking Faith and Justice, cetakan keempat, Maryknoll, New York: Orbis Books, 1986.

. Analisis Sosial dan Refleksi Teologis: Kaitan Iman dan Keadilan, terj. B. Herry-Priyono, Yogyakarta: Kanisius, 1986.
Lembaga Survei Indonesia. Tren Persepsi Publik tentang Demokrasi, Korupsi, dan Intoleransi: Temuan Survei Nasional 1-7 Agustus 2018 (Jakarta: Lembaga Survei Indonesia, 2018).

Markus, R. A. Saeculum: History and Society in the Theology of St. Augustine, Cambridge: Cambridge University Press, 1970.

Martini, Carlo M. The Dove at Rest, Kildare, Irlandia: St. Pauls, 1995.

Pertana, Pradito Dita. "Perbedaan Agama Membuat Slamet Ditolak Tinggal di Dusun Karet Bantul", DetikNews, 2 April 2019, tersedia dari https://news.detik.com/berita-jawa-tengah/d-4494241/perbedaan-agama-membuat-slamet-ditolak-tinggal-didusun-karet-bantul; diakses 11 April 2019.

PPIM UIN Jakarta-UNDP Indonesia. "Sikap dan Perilaku Keberagaman Guru dan Dosen Pendidikan Agama Islam", Convey Report, Vol. 1, No. 9 Th. 2018.

SETARA Institute. "Laporan Tengah Tahun Kondisi Kebebasan Beragama/Berkeyakinan dan Minoritas Keagamaan di Indonesia 2018" (20 Agustus 2018), tersedia dari http://setara-institute.org/laporantengah- tahun-kondisi-kebebasan-berag a m aberkey akin a n - d a n - min oritas keagamaan-di-indonesia-2018/; diakses 20 Mei 2019.

"Ringkasan Eksekutif Indeks Kota Toleran Tahun 2018” (7 Desember 2018), tersedia dari https://drive.google.com/ file/d/1SR3-7tWpb16QpyyIydHB nm8eLiqEPjHp/view; diakses 21 Mei 2019.

Social Progress Imperative. "2018 Social Progress Index" (21 September 2018), tersedia dari https://www.socialprogress. org $/$ tab $=2 \&$ code $=$ IDN\&compare $=$ IDN\&prop=BHN; diakses 20 Mei 2019. 
